\title{
Application of Advanced Oxidation
}

Processes for Treatment of Air from

Livestock and Industrial Facilities

Department of Engineering

Hongqing Yao

PhD Thesis 
ISBN: 978-87-7507-320-7

DOI: http://dx.doi.org/10.7146/aul.13.12 


\section{APPLICATION OF ADVANCED OXIDATION PROCESSES FOR TREATMENT OF AIR FROM LIVESTOCK AND INDUSTRIAL FACILITIES}

\section{HONGQING YAO}

PhD THESIS · SCIENCE AND TECHNOLOGY · 2015

Department of Engineering Hangøvej 2

DK-8200 Aarhus N 


\section{Preface}

This PhD-thesis, submitted in May 2015, forms a part of the fulfilments of my PhD degree. The research was totally funded by Faculty of Science and Technology, Aarhus University. All studies included in this thesis were conducted at the Department of Engineering, Faculty of Science and Technology, Aarhus University, during the period of February 2011 to May 2015. My work was supervised by Anders Feilberg as my main supervisor and by Anders Peter S. Adamsen and Michael Jørgen Hansen as my co-supervisors.

This thesis focuses on application of advanced oxidation processes for odour abatement and comprises an introduction section describing the current research background, hypothesis and objectives (Section 1), challenges of photocatalysis and the peroxone process (Section 2), analytical methodology (Section 3), description of the reactor (Section 4), the main findings and discussions (Section 5), the major conclusions (Section 6) and the perspectives (Section 7). Six manuscripts were produced in this $\mathrm{PhD}$ study and attached at the end.

I would like to use this opportunity to first acknowledge my main supervisor Anders Feilberg. Your immense knowledge and positive outlook guided and encouraged me through the development of the whole $\mathrm{PhD}$ project. I am truly thankful for your steadfast integrity and thoughtful care to both my academic and personal development. Also great thanks to my co-supervisors, Michael Jørgen Hansen and Anders Peter S. Adamsen. Thank you for always instant feedback and inspiring chatting. I would also like to acknowledge the great colleagues in Group of Air Quality Engineering for a very enjoyable working environment and nice social events through my working period in Denmark. Particularly, thanks my officemate, Christina, for helping me the daily work and thank you for non-work related discussions. I deliver my gratitude to the laboratory technician Simon for helping build up my reactors. I would like to thank my friends for their support and making my PhD life colourful. Last, but definitely not least, I would like to thank my husband Kun and our lovely daughter Anja for the great support and being there for me all the time. At the same time, I would like to thank my parents for the continuous encouragement.

Aarhus, May, 2015,

Hongqing Yao 姚宏清 


\section{Summary}

Odours emitted from livestock and industrial facilities are unpleasant, and they can cause tension between producers and nearby residents and negatively affect their quality of life. It is necessary to develop proper air cleaning technologies for odour abatement. However, current technologies are limited by the removal efficiency and by the selectivity towards certain odorants. In particular, removal of reduced sulphur compounds is a challenge. Advanced oxidation processes (AOPs), as a set of chemical reactions to generate $\mathrm{OH}$ - radicals, are considered as an alternative technology to overcome the limitations, because the $\mathrm{OH}$ - radical is a relatively non-selective reactant and can react with a wide range of compounds with high reaction rate. The key hypothesis of the current $\mathrm{PhD}$-project is that the odorous compounds emitted from livestock and industrial facilities, especially reduced sulphur compounds, can be effectively removed by the AOP-based reactors. The objectives were: 1) to develop AOP-based reactors for odour abatement, 2) to assess the removal efficiency of odorous compounds by using AOPs, 3) to characterize the AOP processes in detail, including assessment of the role of hydroxyl radicals, 4) to investigate relevant by-products after the AOPs from the reactors, and 5) to identify possibilities for optimization of the AOP processes.

Two types of AOP-based reactors were designed and assessed: 1) photocatalytic monolith reactors $\left(\mathrm{UV} / \mathrm{TiO}_{2}\right)$ and 2) wet scrubbers run with the peroxone process $\left(\mathrm{O}_{3}+\mathrm{H}_{2} \mathrm{O}_{2}\right)$. The processing conditions were attempted to be close to realistic conditions, such as high air flow rates and low residence time, low initial concentration (ppbv level), room temperature and ambient pressure. Proton-transfer-reaction mass spectrometry (PTR-MS) was used to monitor the concentrations of the odorous compounds before and after the reactor, as well as to investigate the Langmuir-Hinshelwood kinetic data for photocatalytic oxidation of reduced organic sulphur compounds with low adsorption. By-products from the two reactors were detected by PTR-MS, gas chromatography with mass spectrometry and gas chromatography with sulphur chemiluminescence detection.

Two photocatalytic monolith reactors were assessed. A bench-scale reactor, with one $\mathrm{TiO}_{2}$ filter installed, was used for evaluating potential influencing factors (initial concentration, air flow rates and UV intensity), establishing Langmuir-Hinshelwood model for kinetic studies of reduced sulphur compounds (methanethiol (MT), dimethyl sulphide (DMS), and dimethyl disulphide (DMDS)) and for investigating their by-product. More than $80 \%$ of the concentrations of reduced sulphur compounds can typically be removed at a residence time greater than $0.12 \mathrm{~s}$ and at the initial concentration lower than $150 \mathrm{ppbv}$. Data from PTR-MS were fitted very well by the Langmuir-Hinshelwood kinetic model (generally $R^{2}>0.99$ ) with uncertainties of $<20 \%$ on Langmuir adsorption constants $(\mathrm{K})$ and reaction rate constants $(\mathrm{k})$. It is the first time to present the uncertainty of the kinetic model for highly volatile compounds. According to the investigation of the byproducts, odour was significantly removed by photocatalytic oxidation of MT and DMDS. However, around $2 \%$ of DMS was oxidised to MT, which has a low odour threshold value $(0.07 \mathrm{ppbv})$, to the extent that 
degradation of DMS is predicted (based on odour threshold values) to increase odour. Furthermore, all reduced organic sulphur compounds produced formaldehyde, which is a carcinogen. In order to reduce the production of by-products, it is suggested to connect an additional $\mathrm{TiO}_{2}$ filter in series to remove MT and formaldehyde. In a pilot-scale reactor with three $\mathrm{TiO}_{2}$ filters installed, removal of eight odorous compounds (reduced sulfur compounds, carboxylic acids and 1-butanol) was tested and more than $80 \%$ of them could be removed at a residence time greater than $0.1 \mathrm{~s}$. However, $\mathrm{H}_{2} \mathrm{~S}$ could not be effectively removed from the current photocatalytic reactors, and it is suggested that the application of the investigated technology is best suited for the abatement of odours that do not contain $\mathrm{H}_{2} \mathrm{~S}$.

Two types of wet scrubbers run with the peroxone process $\left(\mathrm{O}_{3}+\mathrm{H}_{2} \mathrm{O}_{2}\right)$ were also investigated. More than $90 \%$ of DMS could be removed in a bubble reactor with the peroxone process. Therefore, a packed-bed wet scrubber with direct air injection of $\mathrm{O}_{3}$ was assessed. Both $\mathrm{H}_{2} \mathrm{~S}$ and DMS could be removed at with efficiency above 90\%. However, the removal of MT was not as high as $\mathrm{H}_{2} \mathrm{~S}$ and DMS (23.5\%). It is suggested that $\mathrm{O}_{3}$ is the main reactant in the packed-bed scrubber, and that $\mathrm{OH}$. radicals play a minor role under the conditions applied. Therefore, it is necessary to improve the wet scrubber. In addition, there was an excess $\mathrm{O}_{3}$ emission, and further optimization is needed to optimise the $\mathrm{O}_{3}$ uptake and to reduce the outlet concentration of $\mathrm{O}_{3}$.

In this PhD-project a thorough examination of the potential of using AOP for air cleaning with focus on odour reduction and removal of volatile sulfur compounds. Two AOP-based reactors were assessed at processing conditions close to realistic operating conditions. The photocatalytic monolith reactor could effectively remove most of the odorous compounds, except $\mathrm{H}_{2} \mathrm{~S}$, and the packed bed wet scrubber was effective on removal of $\mathrm{H}_{2} \mathrm{~S}$ and DMS, but not on MT. Therefore, appropriate techniques have to be carefully selected to maximise the odour removal. Further research is necessary to optimise the reactor setup and apply the reactor on site. 


\section{Resumé}

Emission af lugt fra intensiv husdyrproduktion og industrielle faciliteter giver anledning til ubehagelige gener, hvilket kan medføre konflikter mellem producenter og lokalbefolkningen og føre til bl.a. nedsat livskvalitet. Det er derfor nødvendigt at udvikle effektive luftrensningsteknologier til minimering af lugtemissionerne. De teknologier, f.eks. biologisk luftrensning, der hidtil har været anvendt indenfor f.eks, husdyrproduktion har imidlertid ikke haft tilfredsstillende effektivitet og har været begrænset af selektivitet overfor bestemte typer af lugtstoffer. I særdeleshed er rensning af flygtige reducerede svovlforbindelser en udfordring. Avancerede oxidationsprocesser (AOP) er en type af kemiske processer, der har det til fælles, at de alle danner hydroxyl-radikaler $(\mathrm{OH})$. AOP har potentiale til at fungere som alternativ til eksisterende teknologier, da $\mathrm{OH}$-radikaler reagerer uspecifikt og forholdsvis hurtigt med en lang række stoffer, herunder lugtstoffer. Den overordnede hypotese for dette ph-d.-projekt har været at emissioner fra husdyrproduktion og industri effektivt kan renses for lugtstoffer, med hovedvægt på reducerede flygtige svovlforbindelser, ved hjælp af AOP.

Formålene med projektet var følgende: 1) At evaluere rense-effektivitet for relevante lugtstoffer ved anvendelse af AOP, 2) At opnå detaljeret karakterisering af AOP inklusive en evaluering af $\mathrm{OH}$-radikalers rolle, 3) At undersøge forekomsten af relevante reaktionsbiprodukter ved forskellige AOP, 4) At afklare muligheder for optimering af AOP, og 5) at udvikle AOP-reaktorer til eksperimentelle undersøgelser i laboratorieskala.

To typer af AOP-baserede reaktorer blev designet og anvendt til undersøgelserne: 1) En fotokatalytisk reaktor baseret på UV-bestråling af $\mathrm{TiO}_{2}$, og 2) en vandig skrubber med tilsætning af $\mathrm{O}_{3}$ og $\mathrm{H}_{2} \mathrm{O}_{2}$ (betegnet peroxon). Procesbetingelserne blev valgt med henblik på at simulere realistiske driftsbetingelser, dvs. højt luftflow og lav opholdstid, lave indløbskoncentrationer (ppb), stuetemperatur og atmosfærisk tryk. PTR-MS (proton-transfer-reaction mass spectrometry) blev anvendt i udstrakt grad til at måle koncentrationer før og efter de undersøgte filtre og til at opnå kinetiske data ud fra Langmuir-Hinshelwood-analyse af fotokatalytisk oxidation af reducerede flygtige organiske svovlforbindelser med lav adsorption til filter-matricen. Delvist oxiderede biprodukter blev detekteret med PTR-MS, gaskromatografi med massespektrometri (GC-MS) og gas kromatografi med svovlspecifik kemiluminescens detektion (GC-SCD).

To forskellige fotokatalytiske reaktorer blev anvendt til de eksperimentelle undersøgelser. En mindre reaktor i laboratorie-skala med et enkelt $\mathrm{TiO}_{2}$-filter blev undersøgt med henblik på at evaluere faktorer af væsentlig betydning for effektiviteten (start-koncentration, lufthastighed og UV-intensitet), at anvende LangmuirHinshelwood-modellen til at beskrive nedbrydningskinetik for reducerede svovlforbindelser (methanthiol; MT, dimethylsulfid; DMS og dimethyldisulfid; DMDS) og at undersøge dannelsen af biprodukter. Resultaterne viser, at de tre svovlforbindelser kan fjernes med en effektivitet på > $80 \%$ ved en opholdstid 
på $>0.12$ sekunder og en start-koncentration på $<150 \mathrm{ppb}$. Langmuir-Hinshelwood-udtrykket kunne fittes til eksperimentelle PTR-MS-data med meget god overensstemmelse $\left(R^{2}>0,99\right)$. Usikkerhederne på de opnåede adsorptionskoefficienter og hastighedskonstanter var i de fleste tilfælde mindre end 20\%, hvilket opfattes som tilfredsstillende for denne type stoffer. Dette er første gang, at usikkerhederne på udledte LangmuirHinshelwood parametre er angivet for stoffer med lav adsorption. Undersøgelser af de dannede biprodukter viste, at den samlede lugt forventes at kunne fjernes for MT og DMDS. Imidlertid gav fjernelse af DMS anledning til dannelse af MT i et udbytte på ca. 2\%, og da MT har en meget lav lugttærskel (0.07 ppb) medfører dette, at fotokatalytisk nedbrydning af DMS ikke fjernes den del af lugten, der kommer fra DMS, men tværtimod kan føre til forøget lugt.

Desuden gav alle de undersøgte forbindelser anledning til dannelse af formaldehyd i små mængder. Da formaldehyd er sundhedsskadeligt og kræftfremkaldende, skal dette imødegås ved yderligere optimering af processen, f.eks. ved at anvende flere fotokatalytiske filtre i serie. I en større pilot-reaktor med tre UVbelyste $\mathrm{TiO}_{2}$-filtre forbundet i serie, blev fjernelsen af otte lugtstoffer undersøgt (svovlforbindelser, flygtige carboxylsyrer og 1-butanol), og koncentrationerne kunne fjernes med mere end $80 \%$ effektivitet ved opholdstider på >1 sekund. Imidlertid viste forsøgene tydeligt, at $\mathrm{H}_{2} \mathrm{~S}$ ikke kunne fjernes effektivt i den anvendte fotokatalytiske reaktor, og resultaterne tyder dermed på, at teknologien bedst kan anvendes til emissioner, hvor $\mathrm{H}_{2} \mathrm{~S}$ ikke er et vigtigt lugtstof.

To typer a vandige skrubbere baseret på peroxon-processen $\left(\mathrm{O}_{3}+\mathrm{H}_{2} \mathrm{O}_{2}\right)$ blev også undersøgt. Mere end $90 \%$ af DMS kunne fjernes ved en gennembobling i vandig opløsning indeholdende $\mathrm{O}_{3}$ og $\mathrm{H}_{2} \mathrm{O}_{2}$. Ud fra dette blev en packed-bed vandig skrubber konstrueret i laboratorie-skala med tilsætning af ozon direkte til den indgående luft. Både $\mathrm{H}_{2} \mathrm{~S}$ og DMS kunne effektivt fjernes med en effektivitet på > 90\%, hvorimod fjernelsen af MT var forholdsvis lav (24\% i gennemsnit). Samlet tyder resultaterne på, at ozon er den vigtigste reaktant, og at $\mathrm{OH}$-radikaler spiller en mindre rolle under de anvendte fors $ø$ gsbetingelser. Peroxon-processen anvendt til luftrensning bør derfor optimeres yderligere, hvis MT skal fjernes. Endvidere gav processen anledning til emission af ikke-omsat ozon, hvilket bør minimeres ved at optimere ozon-optagelsen eller ved at supplere med et ozon-specifikt sekundært filter.

I dette ph.d.-projekt er gennemført en meget grundig afklaring af potentialet ved anvendelse af AOP til luftrensning med fokus på lugtreduktion og fjernelse af svovlforbindelser. To typer AOP er anvendt under betingelser, der var realistiske for praktisk anvendelse. Fotokatalytisk luftrensning kunne fjerne de fleste lugtstoffer, men ikke $\mathrm{H}_{2} \mathrm{~S}$, hvorimod en peroxon-skrubber var effektiv i forhold til fjernelse af DMS og $\mathrm{H}_{2} \mathrm{~S}$, men ikke MT. AOP til fjernelse af svovlforbindelser i forbindelse med lugtreduktion skal derfor vælges med omhu ud fra den specifikke sammensætning af stoffer. Yderligere optimering af AOP-teknologier er relevant i forhold til praktisk anvendelse. 


\section{List of abbreviations}

1-BA 1-butanoic acid

1-BuOH 1-butanol

1-PrOH 1-propanol

1-VA 1-valeric acid

AA acetic acid

AOPs advanced oxidation processes

DMDS dimethyl disulphide

DMS dimethyl sulphide

DMTS dimethyl trisulphide

ET ethanethiol

$\mathrm{EtOH} \quad$ ethanol

FA formic acid

FID flame ionisation detector

FPD flame photometric detector

GC gas chromatography

K Langmuir adsorption constant

L-H model Langmuir-Hinshelwood model

$\mathrm{MeOH}$ methanol

MID Multiple Ion Detection

MIMS membrane inlet mass spectrometry

MS mass spectrometry 
methanethiol

OAV odour activity value

OTV odour threshold value

PA propionic acid

PTR-MS proton-transfer-reaction mass spectrometry

SCD sulphur chemiluminescence detector

SPME solid-phase microextraction

TMA trimethylamine

VOC volatile organic compound 


\section{Table of Contents}

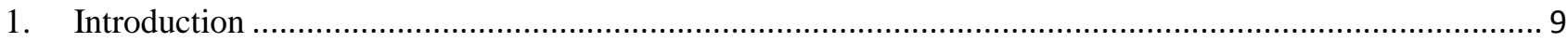

1.1 Offensive odour emissions from livestock and industrial facilities.................................................... 9

1.1.1 Methods of measuring odour and odorous compounds ........................................................ 9

1.1.2 Important odorous compounds from livestock and industrial facilities ................................... 10

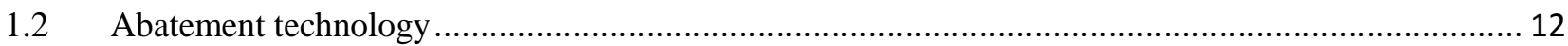

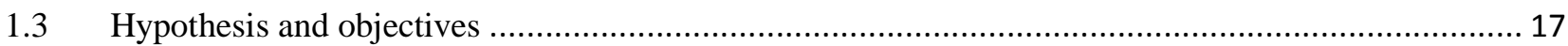

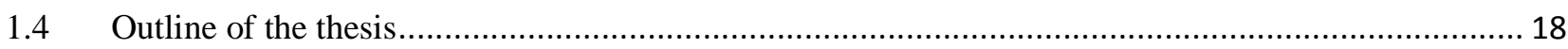

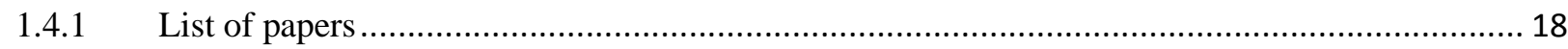

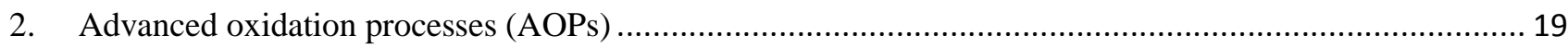

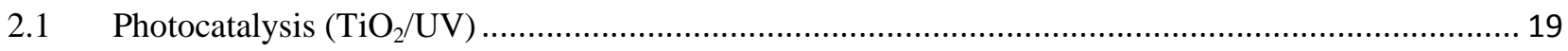

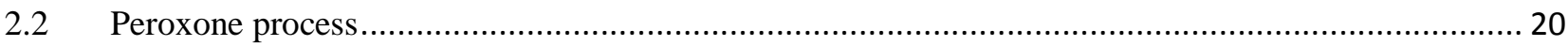

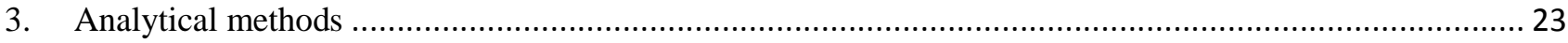

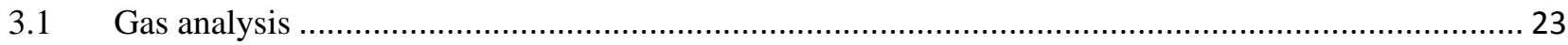

3.1.1 Proton-Transfer-Reaction Mass Spectrometry (PTR-MS) ................................................... 23

3.1.2 Gas Chromatography with Mass Spectrometry (GC/MS) …................................................ 26

3.1.3 Gas Chromatography with Sulphur Chemiluminescence Detector (GC/SCD) ......................... 26

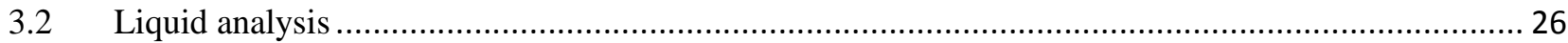

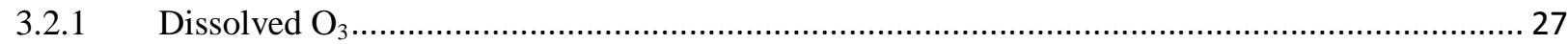

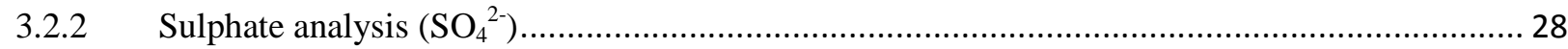

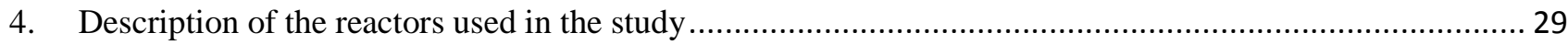

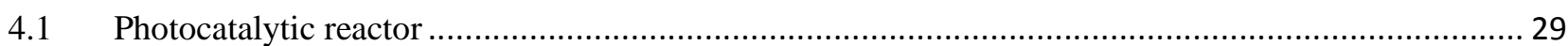

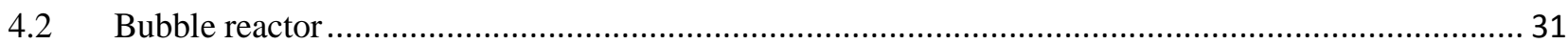

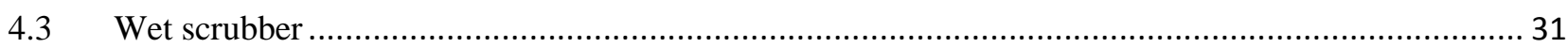

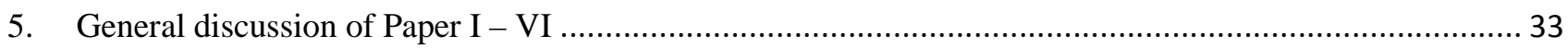

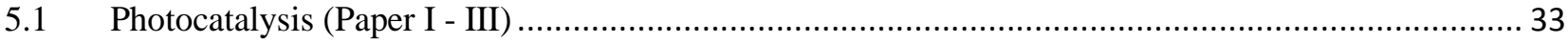

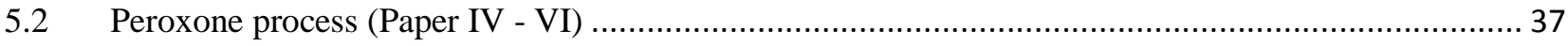

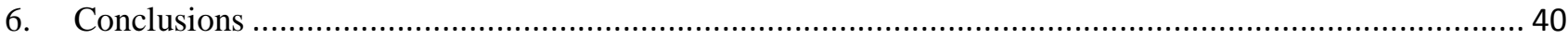

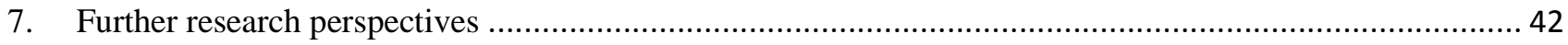

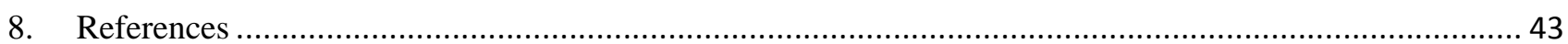




\section{Introduction}

\subsection{Offensive odour emissions from livestock and industrial facilities}

Odour is caused by one or more volatile odorous compounds, and the concentration can be detected by the human olfaction. Odours emitted from livestock and industrial facilities are unpleasant and can be a sever nuisance. They may cause tension between producers and nearby residents, due to the offensive smell which has a negative impact on quality of life [1-3].

\subsubsection{Methods of measuring odour and odorous compounds}

Common method for measuring odour is by the dilution-to-threshold approach which is also known as dynamic olfactometry. The measurement is based on the use of human panellists and is defined as the dilution factor acquired to reach the detection threshold [4]. An odour threshold value (OTV) is defined as the lowest concentration of an odorous compound which can be detected by the human panellist, and OTV can be used to evaluate the odour nuisance from the source. However, the method normally requires the sample collection from the source, and the storage of samples can be up to $30 \mathrm{~h}$ before the analysis according to the European Committee for Standardization [5]. Therefore, it is difficult to measure odours which the odorous compounds are reactive, such as methanethiol which can be oxidised to dimethyl disulphide (DMDS) [6]. In addition, some odorous compounds such as 4-methyl phenol and carboxylic acids have poor recovery in bags and olfactometry, which is another difficulty to accurately measure the odours [7]. Furthermore, the measurement is depending on the human panellists, so the natural variation associated with different humans may influence the measurement even though odor measurements are attempted to be standardized by a common reference compound, 1-butanol. Therefore, measuring the concentration of the odorous compounds is most relevant in addition to using dynamic olfactometry.

Methods for measuring the odorous compounds can be divided into two types: 1) laboratory methods which require sample collection from the source and 2) on-line methods which can directly measure the source on-site. The laboratory methods include gas chromatography with mass spectrometry (GC/MS) and other detectors, such as flame ionisation detector (FID) for general organic compounds, and flame photometric detector (FPD) and sulphur chemiluminescence detector (SCD) specific for sulphur compounds [8-13]. Current sampling methods coupled with the laboratory methods include sampling with adsorbent tubes [14, 15], sampling bags and canisters $[16,17]$ and solid-phase microextraction (SPME) [16, 18-20]. All the chromatographic methods have high selectivity and especially with the GC-MS method, it is able to identify odorous compounds from the sample based on a library search and comparison with standards. However, the laboratory methods have low 
time resolution due to the long analysing time. Furthermore, sampling bags and canisters have also low recovery of some odorous compounds [6,7]. The on-line methods, which include membrane inlet mass spectrometry (MIMS) and proton-transfer-reaction mass spectrometry (PTR-MS), have higher time resolution and both are portable and have high sensitivity [21-23]. However, the humidity in sample air can influence the results obtained by MIMS, which make quantification difficult and in addition high fragmentation makes data interpretation challenging [22]. In contrast, measurement by PTR-MS is more sensitive, more selective due to less ion fragmentation, and has a better time resolution. Both MIMS and PTR-MS require additional methods for identifying the odorous compounds unambiguously. Therefore, the combination of the two complementary methods (laboratory method and on-line method) can substantially advance the measurement of odorous compounds.

\subsubsection{Important odorous compounds from livestock and industrial facilities}

Hundreds of compounds have been identified and quantified from livestock and industrial facilities [24-28]. However, many of the compounds cannot be detected by the human panellists, since the concentration of those compounds are lower than the OTV. To determine the importance of the odorous compounds, odor activity values (OAVs) have been used [23]. OAV can be calculated as mean concentration from the source divided by OTV, so the lower the OTV of the odorous compound, the more likely it is that the odorant is important. In the intensive pig production, the compounds estimated to mainly contribute to odour from the pig house are $\mathrm{H}_{2} \mathrm{~S}$, methanethiol (MT), 1-butanoic acid (1-BA) and 4-methyl phenol [4, 23]. It should be emphasized that the application of OAV is valid only under the assumption that antagonistic and synergistic effects can be disregarded. OAVs of the single compounds can be assumed to be additive [29], although this assumption is difficult to verify. Another approach to determine the key odorous compounds is to correlate odour measured by sensory evaluation to odorous compounds measured by analytical methods by multiple regression statistical methods $[4,30]$.

Important odorous compounds related to livestock and industrial facilities generally belong to the following chemical groups: $\mathrm{N}$ compounds, $\mathrm{S}$ compounds, aldehyde, alcohol, carboxylic acids, and phenols $[15,23,24,31$, 32]. In Table 1 some of the most common odorous compounds are listed with their emission source, odour description and the odour threshold value. 
Table 1 Characteristics of main odorous compounds from livestock and industrial facilities

\begin{tabular}{|c|c|c|c|}
\hline Compounds $^{\mathrm{a}}$ & Emission sources $^{b}$ & Odour description & $\begin{array}{l}\text { OTV }^{\mathrm{c}} \\
\text { ppbv }\end{array}$ \\
\hline \multicolumn{4}{|l|}{ N compounds } \\
\hline ammonia & $\begin{array}{l}\text { Livestock, Wastewater treatment, } \\
\text { Food industry, Alumina refinery }\end{array}$ & Sharp, pungent, suffocating & 1500 \\
\hline TMA & $\begin{array}{l}\text { Livestock, Wastewater treatment, } \\
\text { Food industry }\end{array}$ & Fishy & 0.032 \\
\hline indole & $\begin{array}{l}\text { Livestock, Wastewater treatment, } \\
\text { Tobacco factory }\end{array}$ & Intense faecal & 5.6 \\
\hline 3-methyl indole & Livestock, Wastewater treatment & Faecal odour & 0.054 \\
\hline \multicolumn{4}{|l|}{ S compounds } \\
\hline $\mathrm{H}_{2} \mathrm{~S}$ & $\begin{array}{l}\text { Livestock, Wastewater treatment, } \\
\text { Paper industry, Water reclamation, } \\
\text { Food industry }\end{array}$ & Rotten eggs & 0.41 \\
\hline $\mathrm{CS}_{2}$ & $\begin{array}{l}\text { Livestock, Wastewater treatment, } \\
\text { Food industry }\end{array}$ & Sweet, ether-like & 210 \\
\hline MT & $\begin{array}{l}\text { Livestock, Wastewater treatment, } \\
\text { Paper industry, Alumina refinery }\end{array}$ & Rotten cabbage & 0.07 \\
\hline ET & $\begin{array}{l}\text { Livestock, Wastewater treatment, } \\
\text { Alumina refinery }\end{array}$ & Strong, shunk-like & 0.0087 \\
\hline DMS & $\begin{array}{l}\text { Livestock, Wastewater treatment, } \\
\text { Paper industry, Water reclamation, } \\
\text { Food industry }\end{array}$ & Decayed vegetables & 3.0 \\
\hline DMDS & $\begin{array}{l}\text { Livestock, Wastewater treatment, } \\
\text { Fertilizer industry, Paper industry, } \\
\text { Food industry }\end{array}$ & Putrid garlic & 2.2 \\
\hline DMTS & $\begin{array}{l}\text { Livestock, Fertilizer industry, } \\
\text { Water reclamation, Food industry }\end{array}$ & Strong, onion-garlic & - \\
\hline \multicolumn{4}{|l|}{ Aldehydes } \\
\hline formaldehyde & Livestock & Pungent, suffocating & 500 \\
\hline acetaldehyde & Food industry, Alumina refinery & Pungent, fruity & 1.5 \\
\hline \multicolumn{4}{|l|}{ Alcohols } \\
\hline $\mathrm{MeOH}$ & Livestock & Pungent & 33000 \\
\hline
\end{tabular}


$\mathrm{EtOH}$

1-PrOH

$1-\mathrm{BuOH}$

Carboxylic acids

FA

AA

PA

1-BA

Phenols

phenol

4-methyl phenol
Livestock

Livestock, Bakery, Food industry

Livestock

Livestock

Livestock

Livestock, Food industry

Livestock, Food industry

Livestock, Tobacco factory, Food industry

Livestock irritant

Weak, ethereal, vinous

520

Mild alcohol-like

94

Strong pungent

38

Pungent, penetrating

Sour, vinegar-like, pungent

Pungent, rancid

Sweaty, rancid

0.054

\footnotetext{
${ }^{a}$ TMA - trimethylamine, MT - methanethiol, ET - ethanethiol, DMS - dimethyl sulphide, DMDS - dimethyl disulphide, DMTS - dimethyl trisulphide, $\mathrm{MeOH}$ - methanol, EtOH - ethanol, 1-PrOH - 1-propanol, 1-BuOH - 1-butanol, FA - formic acid, AA - acetic acid, PA - propionic acid, 1-BA - 1-butanoic acid

b $[23-28,33-37]$

${ }^{c}$ OTV - odour threshold value [38].
}

\subsection{Abatement technology}

Considerable efforts have been made in the past few decades to develop odour abatement solutions. Current technologies include biofiltration techniques [22,39] and absorption [40-42] at the exhaust outlets. For livestock production, slurry treatment [43-45] and animal diet manipulation [46, 47] have also been applied for odour abatement. However, the effect of the removal on odorous compounds is highly variable in different processing conditions, abatement technologies and chemical properties of the odorous compounds. The average odour removal using biofilters was $51 \%$ [39] and Hartung et al. even found a higher removal on odour intensity (80 \%) on biofiltration [48]. Furthermore, Liu et al. have found that the removal efficiencies of most odorous compounds in a biofilter were above $80 \%$. However, reduced organic sulphur compounds could not be efficiently removed especially MT and DMS (13\% and 15\%). This result is in agreement with several other studies as well $[22,49,50]$. Currently, scrubbing systems are highly selective with respect to the chemical properties of the odorous compounds: an average up to $96 \%$ efficiency could reach when removing $\mathrm{NH}_{3}$ by acid scrubbing [39, 40], whereas $\mathrm{H}_{2} \mathrm{~S}$ could be effectively removed using base scrubbing [41] and the base scrubbing is also applicable for removal of other compounds that can be deprotonated, such as MT, 4-methyl phenol, and 
carboxylic acids. Furthermore, in livestock production, reduction in dietary crude protein concentrations could only decrease manure ammonia emission, but it could not diminish manure odour offensiveness and VFA concentrations [46]. Generally additives can best be utilized in the manure pit by preventing the odour emission, but it does not work for the surfaces in the animal houses. Therefore, it could only be considered as an early stage of odour abatement treatment. The reduction of ammonia emission could be achieved with acidifying manure or applying additives [44]. Overall, among the important odorous compounds, reduced organic sulphur compounds ( $\mathrm{H}_{2} \mathrm{~S}, \mathrm{MT}$, DMS and DMDS) have lower removal efficiencies than other compounds [22, 49]. Hence, it is necessary to develop new methodologies to remove the reduced sulphur compounds.

Advanced Oxidation Processes (AOPs), as a set of chemical oxidation procedures [51], have originally been introduced into the removal of organic and inorganic contaminants in the water treatment processes. The AOPs generally involves two stages of oxidation: 1) the formation of relatively strong oxidants (e.g., hydroxyl (OH·) radicals) and 2) the reaction of these oxidants with the contaminants. $\mathrm{OH}$. radicals are usually generated by oxidising water with different oxidants such as ozone, $\mathrm{H}_{2} \mathrm{O}_{2}$, catalyst and/or photons (Figure 1), and the $\mathrm{OH}$. radical has a high oxidation potential (Table 2), and can react quickly with a wide range of odorous compounds via a non-selective process in both aqueous and gas phases [52]. Therefore, in the past decades, AOPs are considered as a potential technology to treat contaminated air because they can overcome the limitations from other odour reduction technologies [53]. Table 3 provide the reaction rate constants between key odorous compounds and $\mathrm{OH} \cdot$ radicals [54]. Due to the high reaction rate constants, AOPs have potential as new technologies to reduce the emission of odorous compounds in the air from livestock and industrial facilities, especially the reduced sulphur compounds. Furthermore, the AOPs can be run at room temperature and at ambient pressure. The AOPs studied in this $\mathrm{PhD}$-project were photocatalysis based on UV irradiation of $\mathrm{TiO}_{2}$, and peroxone process $\left(\mathrm{O}_{3} / \mathrm{H}_{2} \mathrm{O}_{2}\right)$ in wet scrubbers. 


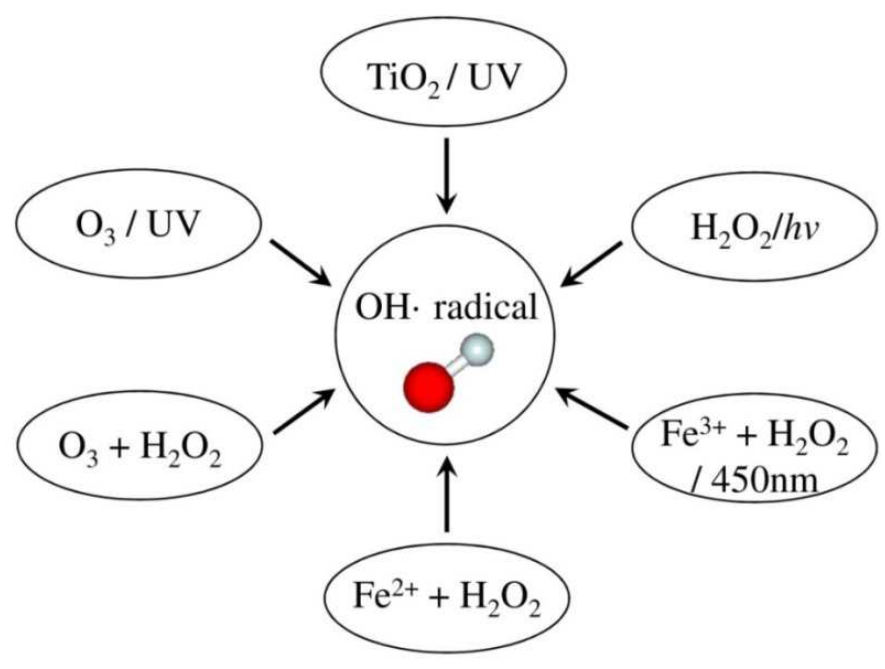

Figure 1 Advanced oxidation processes (AOPs)

Table 2 Standard redox potentials of some oxidising species

\begin{tabular}{ll}
\hline Oxidising species & $\mathbf{E}^{0}(\mathbf{V})^{\text {a }}$ \\
\hline $\mathrm{O}_{2} / \mathrm{H}_{2} \mathrm{O}$ & 1.229 \\
$\mathrm{Cl}_{2} / \mathrm{Cl}^{-}$ & 1.358 \\
$\mathrm{HClO} / \mathrm{Cl}^{-}$ & 1.482 \\
$\mathrm{HClO}_{2} / \mathrm{Cl}^{-}$ & 1.570 \\
$\mathrm{MnO}_{4}-/ \mathrm{MnO}_{2}$ & 1.679 \\
$\mathrm{H}_{2} \mathrm{O}_{2} / \mathrm{H}_{2} \mathrm{O}$ & 1.776 \\
$\mathrm{O}_{3} / \mathrm{O}_{2}$ & 2.076 \\
${\mathrm{positive} \mathrm{charged} \mathrm{hole}\left(\mathrm{h}^{+}\right)}$ & 2.35 \\
$\mathrm{O} / \mathrm{H}_{2} \mathrm{O}$ & 2.421 \\
$\mathrm{OH} \cdot / \mathrm{H}_{2} \mathrm{O}$ & 2.81 \\
$\mathrm{~F}_{2} / \mathrm{F}^{-}$ & 2.866 \\
${ }^{\mathrm{a}} \mathrm{E}^{0}-$ standard redox potential $[55-58]$
\end{tabular}


Table 3 Characteristics of odorous compounds associated with livestock and industrial facilities

\begin{tabular}{|c|c|c|c|c|}
\hline \multirow[t]{2}{*}{ Compound $^{\mathrm{a}}$} & Reaction & $\mathbf{k}^{\mathrm{b}}$ & Reaction & $\mathbf{k}$ \\
\hline & \multicolumn{2}{|l|}{ Aqueous phase $\left(\mathrm{L} \mathrm{mol}^{-1} \mathrm{~s}^{-1}\right)$} & \multicolumn{2}{|l|}{ Gas phase $(298 \mathrm{~K})\left(\mathrm{cm}^{3}\right.$ molecule $\left.^{-1} \mathrm{~s}^{-1}\right)$} \\
\hline \multicolumn{5}{|l|}{ N compounds } \\
\hline ammonia & $\mathrm{NH}_{3}+\mathrm{OH} \cdot \rightarrow \mathrm{H}_{2} \mathrm{O}+\cdot \mathrm{NH}_{2}$ & $9.70 \times 10^{7}$ & $\mathrm{NH}_{3}+\mathrm{OH} \cdot \rightarrow \mathrm{H}_{2} \mathrm{O}+\mathrm{NH}_{2}$ & $1.83 \times 10^{-12}$ \\
\hline TMA & $\left(\mathrm{CH}_{3}\right)_{3} \mathrm{~N}+\mathrm{OH} \cdot \rightarrow\left[\left(\mathrm{CH}_{3}\right)_{3} \mathrm{~N}\right] \cdot \cdot^{+}+\mathrm{H}_{2} \mathrm{O}+\cdot \mathrm{CH}_{2} \mathrm{~N}\left(\mathrm{CH}_{3}\right)_{2}$ & $1.30 \times 10^{10}$ & $\left(\mathrm{CH}_{3}\right)_{3} \mathrm{~N}+\mathrm{OH} \cdot \rightarrow$ Products & $6.11 \times 10^{-11}$ \\
\hline indole & indole $+\mathrm{OH} \cdot \rightarrow$ indole $\mathrm{OH}$-adduct & $3.20 \times 10^{10}$ & indole $+\mathrm{OH} \cdot \rightarrow$ Products & $1.54 \times 10^{-10}$ \\
\hline 3-methyl indole & 3-methylindole $+\mathrm{OH} \cdot \rightarrow$ 3-methylindole $\mathrm{OH}$-adduct & $3.30 \times 10^{10}$ & - & \\
\hline \multicolumn{5}{|l|}{ S compounds } \\
\hline \multirow[t]{2}{*}{$\mathrm{H}_{2} \mathrm{~S}$} & $\mathrm{H}_{2} \mathrm{~S}+\mathrm{OH} \cdot \rightarrow \mathrm{H}_{2} \mathrm{O}+\mathrm{HS}$ & $1.50 \times 10^{10}$ & $\mathrm{H}_{2} \mathrm{~S}+\mathrm{OH} \cdot \rightarrow \mathrm{H}_{2} \mathrm{O}+\mathrm{SH}$ & $4.70 \times 10^{-12}$ \\
\hline & $\mathrm{HS}^{-}+\mathrm{OH} \cdot \rightarrow \mathrm{HSOH}^{-}$ & $9.00 \times 10^{9}$ & & \\
\hline $\mathrm{CS}_{2}$ & $\mathrm{CS}_{2}+\mathrm{OH} \cdot \rightarrow \mathrm{SC}(\mathrm{OH}) \mathrm{S}$ & $8.00 \times 10^{9}$ & $\mathrm{CS}_{2}+\mathrm{OH} \cdot \rightarrow \mathrm{CS}_{2} \mathrm{OH}$ & $8.00 \times 10^{-12}$ \\
\hline MT & $\mathrm{CH}_{3} \mathrm{~S}^{-}+\mathrm{OH} \cdot \rightarrow \mathrm{CH}_{3} \mathrm{~S} \cdot+\mathrm{OH}^{-}$ & $6.00 \times 10^{9}$ & $\mathrm{CH}_{3} \mathrm{SH}+\mathrm{OH} \cdot \rightarrow \mathrm{CH}_{3} \mathrm{~S} \cdot+\mathrm{H}_{2} \mathrm{O}$ & $8.86 \times 10^{-12}$ \\
\hline ET & - & & $\mathrm{CH}_{3} \mathrm{CH}_{2} \mathrm{SH}+\mathrm{OH} \cdot \rightarrow$ Products & $4.65 \times 10^{-11}$ \\
\hline \multirow[t]{3}{*}{ DMS } & $\left(\mathrm{CH}_{3}\right)_{2} \mathrm{~S}+\mathrm{OH} \cdot \rightarrow \mathrm{CH}_{3} \mathrm{~S}(\mathrm{OH}) \mathrm{CH}_{3}$ & $1.90 \times 10^{10}$ & $\left(\mathrm{CH}_{3}\right)_{2} \mathrm{~S}+\mathrm{OH} \cdot \rightarrow\left(\mathrm{CH}_{3}\right)_{2} \mathrm{~S} \cdot \mathrm{OH}$ & $1.70 \times 10^{-12}$ \\
\hline & & & $\left(\mathrm{CH}_{3}\right)_{2} \mathrm{~S}+\mathrm{OH} \cdot \rightarrow \mathrm{H}_{2} \mathrm{O}+\mathrm{CH}_{3} \mathrm{SCH}_{2}$. & $4.80 \times 10^{-12}$ \\
\hline & & & $\left(\mathrm{CH}_{3}\right)_{2} \mathrm{~S}+\mathrm{OH} \cdot \rightarrow \mathrm{CH}_{3} \mathrm{OH}+\mathrm{CH}_{3} \mathrm{~S}$. & 0.04 \\
\hline \multirow[t]{2}{*}{ DMDS } & $\left(\mathrm{CH}_{3} \mathrm{~S}\right)_{2}+\mathrm{OH} \cdot \rightarrow\left[\mathrm{CH}_{3} \mathrm{SSCH}_{3}\right] \cdot^{+}+\mathrm{OH}^{-}$ & $1.70 \times 10^{10}$ & $\left(\mathrm{CH}_{3} \mathrm{~S}\right)_{2}+\mathrm{OH} \cdot \rightarrow \mathrm{CH}_{3} \mathrm{SH}+\mathrm{CH}_{3} \mathrm{SO}$ & 3.00 \\
\hline & & & $\left(\mathrm{CH}_{3} \mathrm{~S}\right)_{2}+\mathrm{OH} \cdot \rightarrow$ Products & $2.30 \times 10^{-10}$ \\
\hline DMTS & - & & - & \\
\hline \multicolumn{5}{|l|}{ Aldehydes } \\
\hline formaldehyde & $\mathrm{HCHO}+\mathrm{OH} \cdot \rightarrow$ Products & $1.00 \times 10^{9}$ & $\mathrm{HCHO}+\mathrm{OH} \cdot \rightarrow$ Products & $1.00 \times 10^{-11}$ \\
\hline acetaldehyde & $\mathrm{CH}_{3} \mathrm{CHO}+\mathrm{OH} \cdot \rightarrow \mathrm{H}_{2} \mathrm{O}+\mathrm{CH}_{3} \mathrm{CO}$ & $3.60 \times 10^{9}$ & $\mathrm{CH}_{3} \mathrm{CHO}+\mathrm{OH} \cdot \rightarrow$ Products & $1.50 \times 10^{-11}$ \\
\hline \multicolumn{5}{|l|}{ Alcohols } \\
\hline $\mathrm{MeOH}$ & $\mathrm{CH}_{3} \mathrm{OH}+\mathrm{OH} \cdot \rightarrow \mathrm{H}_{2} \mathrm{O}+\cdot \mathrm{CH}_{2} \mathrm{OH}$ & $8.30 \times 10^{8}$ & $\mathrm{CH}_{3} \mathrm{OH}+\mathrm{OH} \cdot \rightarrow$ Products & $9.48 \times 10^{-13}$ \\
\hline $\mathrm{EtOH}$ & $\mathrm{CH}_{3} \mathrm{CH}_{2} \mathrm{OH}+\mathrm{OH} \cdot \rightarrow \mathrm{H}_{2} \mathrm{O}+\mathrm{CH}_{3} \mathrm{CHOH}$ & $2.20 \times 10^{9}$ & $\mathrm{CH}_{3} \mathrm{CH}_{2} \mathrm{OH}+\mathrm{OH} \cdot \rightarrow$ products & $3.47 \times 10^{-12}$ \\
\hline 1-PrOH & $1-\mathrm{C}_{3} \mathrm{H}_{7} \mathrm{OH}+\mathrm{OH} \cdot \rightarrow \mathrm{H}_{2} \mathrm{O}+\mathrm{CH}_{3} \mathrm{CH}_{2} \mathrm{CHOH}$ & $2.80 \times 10^{9}$ & $1-\mathrm{C}_{3} \mathrm{H}_{7} \mathrm{OH}+\mathrm{OH} \cdot \rightarrow$ products & $5.50 \times 10^{-12}$ \\
\hline 1-BuOH & $1-\mathrm{C}_{4} \mathrm{H}_{9} \mathrm{OH}+\mathrm{OH} \cdot \rightarrow$ products & $4.20 \times 10^{9}$ & $1-\mathrm{C}_{4} \mathrm{H}_{9} \mathrm{OH}+\mathrm{OH} \cdot \rightarrow$ products & $8.48 \times 10^{-12}$ \\
\hline
\end{tabular}




\section{Carboxylic acids}

\begin{tabular}{|c|c|c|c|c|}
\hline \multirow[t]{2}{*}{ FA } & $\mathrm{HCOOH}+\mathrm{OH} \cdot \rightarrow \mathrm{H}_{2} \mathrm{O}+\cdot \mathrm{CO}_{2} \mathrm{H}$ & $1.30 \times 10^{8}$ & $\mathrm{HCOOH}+\mathrm{OH} \cdot \rightarrow$ products & $4.50 \times 10^{-13}$ \\
\hline & $\mathrm{HCOO}^{-}+\mathrm{OH} \cdot \rightarrow \mathrm{H}_{2} \mathrm{O}+\cdot \mathrm{CO}_{2}^{-}$ & $3.20 \times 10^{9}$ & & \\
\hline \multirow[t]{2}{*}{ AA } & $\mathrm{CH}_{3} \mathrm{COOH}+\mathrm{OH} \cdot \rightarrow \mathrm{H}_{2} \mathrm{O}+\cdot \mathrm{CH}_{2} \mathrm{CO}_{2} \mathrm{H}$ & $1.50 \times 10^{7}$ & $\mathrm{CH}_{3} \mathrm{C}(\mathrm{O}) \mathrm{OH}+\mathrm{OH} \cdot \rightarrow$ products & $8.00 \times 10^{-13}$ \\
\hline & $\mathrm{CH}_{3} \mathrm{COO}^{-}+\mathrm{OH} \cdot \rightarrow \mathrm{H}_{2} \mathrm{O}+\cdot \mathrm{CH}_{2} \mathrm{CO}_{2}^{-}$ & $1.00 \times 10^{8}$ & & \\
\hline \multirow[t]{2}{*}{ PA } & $\mathrm{C}_{2} \mathrm{H}_{5} \mathrm{COOH}+\mathrm{OH} \cdot \rightarrow$ products & $6.20 \times 10^{8}$ & $\mathrm{C}_{2} \mathrm{H}_{5} \mathrm{COOH}+\mathrm{OH} \cdot \rightarrow$ products & $1.20 \times 10^{-12}$ \\
\hline & $\mathrm{C}_{2} \mathrm{H}_{5} \mathrm{COO}^{-}+\mathrm{OH} \cdot \rightarrow$ products & $1.20 \times 10^{9}$ & & \\
\hline \multirow[t]{2}{*}{$1-\mathrm{BA}$} & $1-\mathrm{C}_{3} \mathrm{H}_{7} \mathrm{COOH}+\mathrm{OH} \cdot \rightarrow$ products & $2.20 \times 10^{9}$ & $1-\mathrm{C}_{3} \mathrm{H}_{7} \mathrm{COOH}+\mathrm{OH} \cdot \rightarrow$ products & $1.79 \times 10^{-12}$ \\
\hline & $1-\mathrm{C}_{3} \mathrm{H}_{7} \mathrm{COO}^{-}+\mathrm{OH} \cdot \rightarrow$ products & $2.00 \times 10^{9}$ & & \\
\hline \multicolumn{5}{|l|}{ Phenols } \\
\hline \multirow[t]{2}{*}{ phenol } & $\mathrm{C}_{6} \mathrm{H}_{5} \mathrm{OH}+\mathrm{OH} \cdot \rightarrow$ dihydroxycyclohexadienyl & $6.60 \times 10^{9}$ & $\mathrm{C}_{6} \mathrm{H}_{5} \mathrm{OH}+\mathrm{OH} \cdot \rightarrow$ Products & $2.81 \times 10^{-11}$ \\
\hline & $\mathrm{C}_{6} \mathrm{H}_{5} \mathrm{O}^{-}+\mathrm{OH} \cdot \rightarrow \mathrm{HOC}_{6} \mathrm{H}_{5} \mathrm{O}^{-}$ & $9.60 \times 10^{9}$ & & \\
\hline 4-methyl phenol & $4-\mathrm{CH}_{3} \mathrm{C}_{6} \mathrm{H}_{4} \mathrm{OH}+\mathrm{OH} \cdot \rightarrow$ products & $1.20 \times 10^{10}$ & $4-\mathrm{CH}_{3} \mathrm{C}_{6} \mathrm{H}_{4} \mathrm{OH}+\mathrm{OH} \cdot \rightarrow$ products & $4.96 \times 10^{-11}$ \\
\hline
\end{tabular}

TMA - trimethylamine, MT - methanethiol, ET - ethanethiol, DMS - dimethyl sulphide, DMDS - dimethyl disulphide, DMTS - dimethyl trisulphide, $\mathrm{MeOH}$ - methanol, EtOH - ethanol, 1-PrOH - 1-propanol, 1-BuOH - 1-butanol, FA - formic acid, AA - acetic acid, PA - propionic acid, 1-BA - 1-butanoic acid

b [59-92] 


\subsection{Hypothesis and objectives}

The application of AOPs in drinking water and wastewater treatment plants has been carried out in the past few decades [93-99]. And it has been proven to be a promising technique on the abatement of odorous compounds [100-99]. However, there is limited information on the application of AOP techniques in real livestock and industrial facilities where the air flow rate is normally high with relatively low concentration of those odorous compounds (ppbv level).

Another interesting issue is that in most of the studies, odorous compounds have been mostly measured by GC/FID, GC/FPD or GC/MS [10-13]. Application of direct online MS, on the other hand, is advantageous with respect to avoiding sampling artefacts and obtaining extensive datasets with high time resolution and high precision.

Thus, the main hypothesis of this $\mathrm{PhD}$ project was that the odorous compounds emitted from livestock and industrial facilities, especially reduced sulphur compounds, can be effectively removed by the AOP-based reactors, including $\mathrm{UV} / \mathrm{TiO}_{2}$ and $\mathrm{O}_{3} / \mathrm{H}_{2} \mathrm{O}_{2}$ scrubbers.

The objectives of the $\mathrm{PhD}$ project were:

1) To develop AOP-based reactors for odour abatement

2) To assess the removal efficiency of odorous compounds by using AOPs

3) To characterize the AOP processes in detail, including assessment of the role of hydroxyl radicals by PTR-MS

4) To investigate relevant by-products after the AOPs from the reactors

5) To identify possibilities for optimization of the AOP processes

To achieve these objectives, the studies were performed as follow:

1) Study of photocatalytic oxidation of reduced organic sulphur compounds in a bench-scale honeycomb monolith photocatalytic reactor $\left(\mathrm{UV} / \mathrm{TiO}_{2}\right)$ by means of proton-transfer-reaction mass spectrometry kinetic study, influencing factors in the reactor, by-product investigation and the risk assessment of the by-products

2) Characterisation of photocatalytic oxidation of nine odorous compounds (methanethiol (MT), dimethyl sulphide (DMS), dimethyl disulphide (DMDS), 1-butanol (1-BuOH), acetic acid (AA), propionic acid (PA), 1-butanoic acid (1-BA) and 1-valeric acid (1-VA)) in a pilot-scale honeycomb monolith photocatalytic reactor 
3) DMS removal in a bubble reactor by using peroxone $\left(\mathrm{O}_{3} / \mathrm{H}_{2} \mathrm{O}_{2}\right)$ process

4) Removal of gaseous reduced sulphur compounds $\left(\mathrm{H}_{2} \mathrm{~S}\right.$, DMS and MT) in a wet scrubber coupled with peroxone process

\subsection{Outline of the thesis}

The present $\mathrm{PhD}$-thesis consists of three parts. The first part is a review of the current knowledge regarding the emission of odorous compounds from livestock and industrial facilities and the abatement technologies. The review of emission of odorous compounds includes origin of the odour sources, and the odour description. The abatement technologies include challenges of current technologies and the potential of using AOPs. The second part focuses on the principle and the methodology applied in this study. The third part of the thesis is the experimental results obtained from own experiments. The experimental section is also divided into two subsection: the assessment of photocatalytic reactor (Paper I - III), and the investigation of the wet scrubber combined with peroxone process (Paper IV - VI).

\subsubsection{List of papers}

Paper I: Yao, H., A. Feilberg. Photocatalytic oxidation of reduced organic sulphur compounds by $\mathrm{TiO}_{2}$ photocatalysis: Influencing factors and kinetic study. Paper draft.

Paper II: Yao, H., A. Feilberg. Photocatalytic oxidation of reduced organic sulphur compounds by $\mathrm{TiO}_{2}$ photocatalysis: Determination and risk assessment of by-products and pathway study. Paper draft.

Paper III: Yao, H., A. Feilberg. 2015. Characterisation of photocatalytic degradation of odorous compounds associated with livestock facilities by means of PTR-MS. Chemical Engineering Journal. 277: 341-351.

Paper IV: Yao, H., A. Feilberg. Measurement of dissolved ozone in low concentration ranges and hydroxyl radical yield from ozonated deionised water, alkaline and $\mathrm{H}_{2} \mathrm{O}_{2}$ solution. Paper draft.

Paper V: Yao, H., M.J. Hansen, A. Feilberg. 2014. DMS Removal in a Bubble Reactor by Using Peroxone $\left(\mathrm{O}_{3} / \mathrm{H}_{2} \mathrm{O}_{2}\right)$ Reactions. Chemical Engineering Transactions 40: 229-234.

Paper VI: Yao, H., M.M. Løkke, A. Feilberg. Effects of a packed-bed wet scrubber coupled with peroxone process $\left(\mathrm{O}_{3}+\mathrm{H}_{2} \mathrm{O}_{2}\right)$ on removal of gaseous reduced sulphur compounds. Paper draft. 


\section{Advanced oxidation processes (AOPs)}

\subsection{Photocatalysis $\left(\mathrm{TiO}_{2} / \mathrm{UV}\right)$}

The basis of photocatalysis is the photo-excitation of a semiconductor material (such as e.g., $\mathrm{TiO}_{2}, \mathrm{ZnO}, \mathrm{Fe}_{2} \mathrm{O}_{3}$, $\mathrm{CdS}$, and $\mathrm{ZnS})$. Among the different semiconductor materials, Titanium dioxide $\left(\mathrm{TiO}_{2}\right)$ is the most common semiconductor used in photocatalysis [103]. Under near UV irradiation, $\mathrm{TiO}_{2}$ can be excited and produce electrons in the conduction band $\left(\mathrm{e}_{\mathrm{CB}}{ }^{-}\right)$and positively charged holes in a valence band $\left(\mathrm{h}_{\mathrm{VB}}{ }^{+}\right)$(Reaction 1). The positively charged hole itself on $\mathrm{TiO}_{2}$ has a high oxidation potential of $2.53 \mathrm{~V}$ [56] and so it can directly oxidize the odorous compounds absorbed on the surface of $\mathrm{TiO}_{2}$. Moreover, the positively charged holes can further react with molecular water adsorbed on the surface of $\mathrm{TiO}_{2}$ to produce hydroxyl $(\mathrm{OH} \cdot$ ) radicals (Reactions 2). At the meantime, the superoxide radical $\mathrm{O}_{2} \cdot{ }^{-}$produced by a free electron and molecular oxygen (Reaction 3) can be partly oxidized to singlet oxygen (Reaction 4) which is also a potential oxidant to react with reduced sulphur compounds [104, 105].

$\mathrm{TiO}_{2}+h v \rightarrow \mathrm{h}^{+}+\mathrm{e}^{-}$

Reaction 1

$\mathrm{h}^{+}+\mathrm{H}_{2} \mathrm{O} \rightarrow \mathrm{OH} \cdot+\mathrm{H}^{+}$

Reaction 2

$\mathrm{e}^{-}+\mathrm{O}_{2} \rightarrow \mathrm{O}_{2}$

Reaction 3

$\mathrm{O}_{2} \cdot{ }^{-}+\mathrm{h}^{+} \rightarrow{ }^{1} \mathrm{O}_{2}$

Reaction 4

The advantages of the $\mathrm{UV} / \mathrm{TiO}_{2}$ system are:

1) $\mathrm{TiO}_{2}$ can be excited at higher wavelengths (UV-A: $400-315 \mathrm{~nm}$ ) than other UV oxidation processes $[101,99,106]$, so it is not as energy consuming as UV-B (315 - $280 \mathrm{~nm})$ or UV-C (280 - $100 \mathrm{~nm})$. Furthermore, UV-A has less negative effect to the human health.

2) The photocatalytic oxidation process has been studied for many organic compounds in gas phase [11, $100,107-110]$.

3) The gas can be treated in a short contact time due to the high reaction rate (Paper III) [111].

The challenges of the $\mathrm{TiO}_{2}$ system are:

1) Currently, full-scale application tested in the livestock and industrial facilities has not been reported, but the pilot-scale photocatalytic reactor has been tested at realistic conditions (Paper III) [111]. 
2) $\mathrm{UV} / \mathrm{TiO}_{2}$ system is not fit for treating contaminated air containing high concentration of nitrogen compounds, such as trimethylamine, and sulphur compounds, such as dimethyl sulphide and dimethyl disulphide. Because their by-products, e.g. ammonium and sulphate ion, can accumulate on the $\mathrm{TiO}_{2}$ surface and cause fouling of the active $\mathrm{TiO}_{2}$ sites [112-111].

3) $\mathrm{H}_{2} \mathrm{~S}$ cannot be efficiently removed in the photocatalytic reactor with only $\mathrm{TiO}_{2}$ (Paper III) [111], and $\mathrm{TiO}_{2}$ has to be modified by doping other types of photocatalyst or metals on $\mathrm{TiO}_{2}$ [115-117].

Therefore, $\mathrm{TiO}_{2} / \mathrm{UV}$ photocatalytic oxidation is recommended in the indoor applications (e.g., office and apartment) and for treating contaminated air with low contaminant concentrations. This technology for odour abatement is promising, and it still needs further improvement, such as optimising the number of UV lamps in the photocatalytic reactor, so it can minimise energy consumption, or optimising the active surface area and the amount of the photocatalyst, so it can not only maintain a high removal efficiency of odorous compounds, but also minimise formation of unwanted by-products, which may be even worse than the original odorous compounds. Furthermore, additional studies are needed to evaluate the effect of the large-scale photocatalytic reactor in the real livestock and industrial facilities on removal of contaminants in gas phase.

\subsection{Peroxone process}

The standard redox potential of ozone is $2.706 \mathrm{~V}$, which is also a relatively highly oxidising species (Table 2). However, ozone is a highly selective oxidant, which can only rapidly react with compounds containing electronrich moieties, such as compounds containing double bonds, phenols, and amine moieties [98, 118]. Table 4 presents the comparison of reaction rate between $\mathrm{OH} \cdot$ radicals and $\mathrm{O}_{3}$ with odorous compounds in aqueous and gas phase, and for the same compound, the reactions with $\mathrm{OH}$. radicals are all faster than the reactions with $\mathrm{O}_{3}$ in both gas and aqueous phases. Therefore, it is expected that $\mathrm{O}_{3}$-based AOP is an effective approach to treat the contaminated air by using both $\mathrm{O}_{3}$ and $\mathrm{OH}$. radicals. The reaction of $\mathrm{O}_{3}$ with $\mathrm{H}_{2} \mathrm{O}_{2}$ is known as the peroxone process and it has been introduced mainly to purify drinking water [119]. Though the reaction between $\mathrm{O}_{3}$ and $\mathrm{H}_{2} \mathrm{O}_{2}\left(\mathrm{k}<0.01 \mathrm{M}^{-1} \mathrm{~s}^{-1}\right)$ is slow [119], the reaction between $\mathrm{O}_{3}$ and the anion of $\mathrm{H}_{2} \mathrm{O}_{2}\left(\mathrm{HO}_{2}{ }^{-}\right)$(Reaction 5) is much faster $\left(\mathrm{k}=2.8 \times 10^{6} \mathrm{M}^{-1} \mathrm{~s}^{-1}\right)[120]$.

$\mathrm{O}_{3}+\mathrm{HO}_{2}^{-} \rightarrow \mathrm{O}_{2}+\mathrm{OH} \cdot+\mathrm{O}_{2}{ }^{-}$

Reaction 5

Due to the faster reaction rate between $\mathrm{O}_{3}$ and $\mathrm{HO}_{2}{ }^{-}$, it is expected that higher $\mathrm{pH}$ is more efficient for production of $\mathrm{OH}$. radicals. Furthermore, Reaction 5 has been proposed since 1985 [119], and one mole of OH. radical could be produced from one mole of $\mathrm{O}_{3}$. However, a recent study has proposed a more detailed kinetic scheme 
and the rate of $\mathrm{OH}$. radical formation in the peroxone process has been found to be half of the rate of $\mathrm{O}_{3}$ decay. (Reaction 6-8) [121].

$\mathrm{O}_{3}+\mathrm{HO}_{2}^{-} \rightarrow \mathrm{HO}_{5}^{-}$

Reaction 6

$\mathrm{HO}_{5}{ }^{-} \rightarrow \mathrm{HO}_{2} \cdot+\mathrm{O}_{3} \cdot{ }^{-}$

Reaction 7

$\mathrm{HO}_{2} \cdot+\mathrm{O}_{3} \rightarrow 2 \mathrm{O}_{2}+\mathrm{OH} \cdot$

Reaction 8

Table 4 Comparison of reaction rate between $\mathrm{OH} \cdot$ radicals and $\mathrm{O}_{3}$ with odorous compounds in both aqueous and gas phases ${ }^{a}$

\begin{tabular}{|c|c|c|c|c|}
\hline \multirow[t]{2}{*}{ Compound $^{\text {b }}$} & \multicolumn{2}{|c|}{ Aqueous phase } & \multicolumn{2}{|l|}{ Gas phase } \\
\hline & $\begin{array}{l}\mathrm{k} / \mathrm{OH} \cdot \\
\left(\mathrm{L} \mathrm{mol}^{-1} \mathrm{~s}^{-1}\right)\end{array}$ & $\mathrm{k} / \mathrm{O}_{3}$ & $\begin{array}{l}\mathrm{k} / \mathrm{OH} \cdot \\
\left(\mathrm{cm}^{3} \text { molecule }^{-1} \mathrm{~s}^{-1}\right.\end{array}$ & $\mathbf{k} / \mathrm{O}_{3}$ \\
\hline $\mathrm{NH}_{3}$ & $9.70 \times 10^{7}$ & 20 & $1.83 \times 10^{-12}$ & - \\
\hline TMA & $1.30 \times 10^{10}$ & 4.1 & $6.11 \times 10^{-11}$ & $7.84 \times 10^{-18}$ \\
\hline Indole & $3.20 \times 10^{10}$ & - & $1.54 \times 10^{-10}$ & $4.90 \times 10^{-17}$ \\
\hline 3-Methyl indole & $3.30 \times 10^{10}$ & - & - & - \\
\hline $\mathrm{H}_{2} \mathrm{~S}$ & $1.50 \times 10^{10}$ & $3.00 \times 10^{4}$ & $4.70 \times 10^{-12}$ & $2.62 \times 10^{-12}$ \\
\hline $\mathbf{C S}_{2}$ & $8.00 \times 10^{9}$ & - & $8.00 \times 10^{-12}$ & - \\
\hline MT & $6.00 \times 10^{9 c}$ & - & $8.86 \times 10^{-12}$ & - \\
\hline ET & - & $2.00 \times 10^{5}$ & $4.65 \times 10^{-11}$ & - \\
\hline DMS & $1.90 \times 10^{10}$ & $4.00 \times 10^{8}$ & $1.70 \times 10^{-12}$ & $9.96 \times 10^{-11}$ \\
\hline DMDS & $1.70 \times 10^{10}$ & - & $2.30 \times 10^{-10}$ & - \\
\hline DMTS & - & - & - & - \\
\hline formaldehyde & $1.00 \times 10^{9}$ & 0.1 & $1.00 \times 10^{-11}$ & $2.09 \times 10^{-24}$ \\
\hline acetaldehyde & $3.60 \times 10^{9}$ & 1.5 & $1.50 \times 10^{-11}$ & $3.40 \times 10^{-20}$ \\
\hline МeOH & $8.30 \times 10^{8}$ & 0.02 & $9.48 \times 10^{-13}$ & - \\
\hline EtOH & $2.20 \times 10^{9}$ & 0.51 & $3.47 \times 10^{-12}$ & - \\
\hline 1-PrOH & $2.80 \times 10^{9}$ & 0.37 & $5.50 \times 10^{-12}$ & - \\
\hline 1-BuOH & $4.20 \times 10^{9}$ & 1.1 & $8.48 \times 10^{-12}$ & - \\
\hline FA & $1.30 \times 10^{8}$ & 5 & $4.50 \times 10^{-13}$ & - \\
\hline $\mathbf{A A}$ & $1.50 \times 10^{7}$ & $3.00 \times 10^{-5}$ & $8.00 \times 10^{-13}$ & - \\
\hline $\mathbf{P A}$ & $6.20 \times 10^{8}$ & $4.00 \times 10^{-4}$ & $1.20 \times 10^{-12}$ & - \\
\hline 1-BA & $2.20 \times 10^{9}$ & 0.006 & $1.79 \times 10^{-12}$ & - \\
\hline
\end{tabular}




\begin{tabular}{lllll}
\hline Phenol & $6.60 \times 10^{9}$ & $1.30 \times 10^{3}$ & $2.81 \times 10^{-11}$ & - \\
4-Methyl phenol & $1.20 \times 10^{10}$ & $1.50 \times 10^{4}$ & $4.96 \times 10^{-11}$ & $4.72 \times 10^{-19}$ \\
\hline
\end{tabular}

${ }^{\mathrm{a}}[59-91,122-137][92]$

b TMA - trimethylamine, MT - methanethiol, ET - ethanethiol, DMS - dimethyl sulphide, DMDS - dimethyl disulphide, DMTS - dimethyl trisulphide, $\mathrm{MeOH}$ - methanol, EtOH - ethanol, 1-PrOH - 1-propanol, 1-BuOH - 1-butanol, FA - formic acid, AA - acetic acid, PA - propionic acid, 1-BA - 1-butanoic acid

${ }^{c}$ It is the reaction rate constant between $\mathrm{OH} \cdot$ radical and methanethiol ion $\left(\mathrm{CH}_{3} \mathrm{~S}^{-}\right)$

The advantages of using peroxone process are:

1) The peroxone process is more effective at removing odorous compounds than $\mathrm{O}_{3}$ or $\mathrm{H}_{2} \mathrm{O}_{2}$ alone, because the peroxone process can produce $\mathrm{OH} \cdot$ radicals, rather than just $\mathrm{O}_{3}$, and peroxone also allows a lower using dosage of $\mathrm{O}_{3}$, which is desirable for reducing costs.

2) According to the literature reviews, peroxone appears to be the most tested and applied AOPs in purification of drinking water and wastewater, relative to the other AOPs [93-99].

3) In this $\mathrm{PhD}$ project, it has been demonstrated that both $\mathrm{H}_{2} \mathrm{~S}$ and DMS could be effectively removed at $\mathrm{pH}$ level above 8.0 by peroxone process (Paper V and VI).

The challenges and limitations of the peroxone process are:

1) Although peroxone process has been studied on water treatment, there are limited studies aimed at purifying contaminated air by using peroxone process.

2) Improper use of $\mathrm{O}_{3}$ can cause an excessive emission which is harmful for the environment.

3) Wet scrubber coupled with the peroxone process is a relatively common approach for the water treatment when applying AOPs. However, it is a challenge to find proper packing materials for the gas treatment which is required to be surface inactive, and do not react with $\mathrm{O}_{3}, \mathrm{H}_{2} \mathrm{O}_{2}$ or $\mathrm{OH}$. radicals.

Overall, the technique of wet scrubber coupled with peroxone process for removing odorous compounds is promising. However, it requires further optimization to be applied in the real situation. Additional studies are necessary to improve the technique, such as to characterise the process with respect to degradation of a range of gaseous compounds, to investigate the role of $\mathrm{OH}$ - radicals at different conditions, to increase the utilization rate of $\mathrm{O}_{3}$, and to find proper packing materials in the wet scrubber. 


\section{Analytical methods}

This $\mathrm{PhD}$-thesis includes a set of process studies, which were conducted with laboratory experiments. In the following section, the applied methodologies are discussed.

\subsection{Gas analysis}

The measurement of odorous compounds is the main target in this study. A variety of methods have been used $[9-13,108,138]$. Each method has strengths and weaknesses that need to be matched with the objectives of a particular study. Here, only methods relevant to the present PhD study are discussed.

\subsubsection{Proton-Transfer-Reaction Mass Spectrometry (PTR-MS)}

Proton-transfer-reaction mass spectrometry (PTR-MS) is used for online measurements of odorous compounds, and the Online PTR-MS is a time-resolved $(<1 s)$ instrument with very low detection limit on measuring odorous compounds (pptv level). Furthermore, the PTR-MS has been applied in measuring odour emission and monitoring the reaction processes $[23,108,139]$.

In PTR-MS, protonated water $\left(\mathrm{H}_{3} \mathrm{O}^{+}\right)$is used as a chemical ionisation reagent to ionise compounds (R) as Reaction 9. Therefore, the molecules are protonated, accelerated by an electric field, and separated according to their mass-to-charge ratio $(\mathrm{m} / \mathrm{z})$. For example, the molecule weight of dimethyl sulphide (DMS) is 62 , and the concentration of DMS is the concentration of $\mathrm{m} / \mathrm{z} 63$, which represents protonated DMS.

$\mathrm{R}+\mathrm{H}_{3} \mathrm{O}^{+} \rightarrow \mathrm{RH}^{+}+\mathrm{H}_{2} \mathrm{O}$

Reaction 9

The PTR-MS consists of 1) an ion source to produce the $\mathrm{H}_{3} \mathrm{O}^{+}$ions, 2) a drift tube reactor, where the protontransfer reaction takes place, 3) a quadrupole mass spectrometer for the detection of the ions (Figure 2) [21]. To be noticed, the proton affinity of water is $691 \mathrm{~kJ} \mathrm{~mol}^{-1}$ and only compounds with proton affinities above $691 \mathrm{~kJ}$ $\mathrm{mol}^{-1}$ can be detected by PTR-MS, which makes it impossible for this technique to detect the oxidation end products, such as $\mathrm{CO}_{2}$ and $\mathrm{SO}_{2}$, due to their low proton affinities. In addition, the chemical ionisation in PTRMS results in low fragmentation and it is difficult to distinguish the isomers or the compounds with similar molecule weight. Therefore, for known compounds, PTR-MS is a time-resolved instrument to monitor the emission or reaction processes. However, for unknown compounds, it is difficult to identify the composition of the air by only using PTR-MS and supplementary measurements, such as GC/MS and other methods, are necessary to assist the identification. In this PhD-project, PTR-MS was mainly used for monitoring the effect of reactors on removal of single odorous compounds (Paper I, III, V and VI). Furthermore, the kinetics (Paper I) 
and the by-products (Paper II and III) from photocatalytic reactor were investigated. There are two modes in PTR-MS, multiple ion detection (MID) mode and full-scan mode. MID mode is used for monitoring single compounds, while full-scan mode is normally applied for detecting unknown air sample.

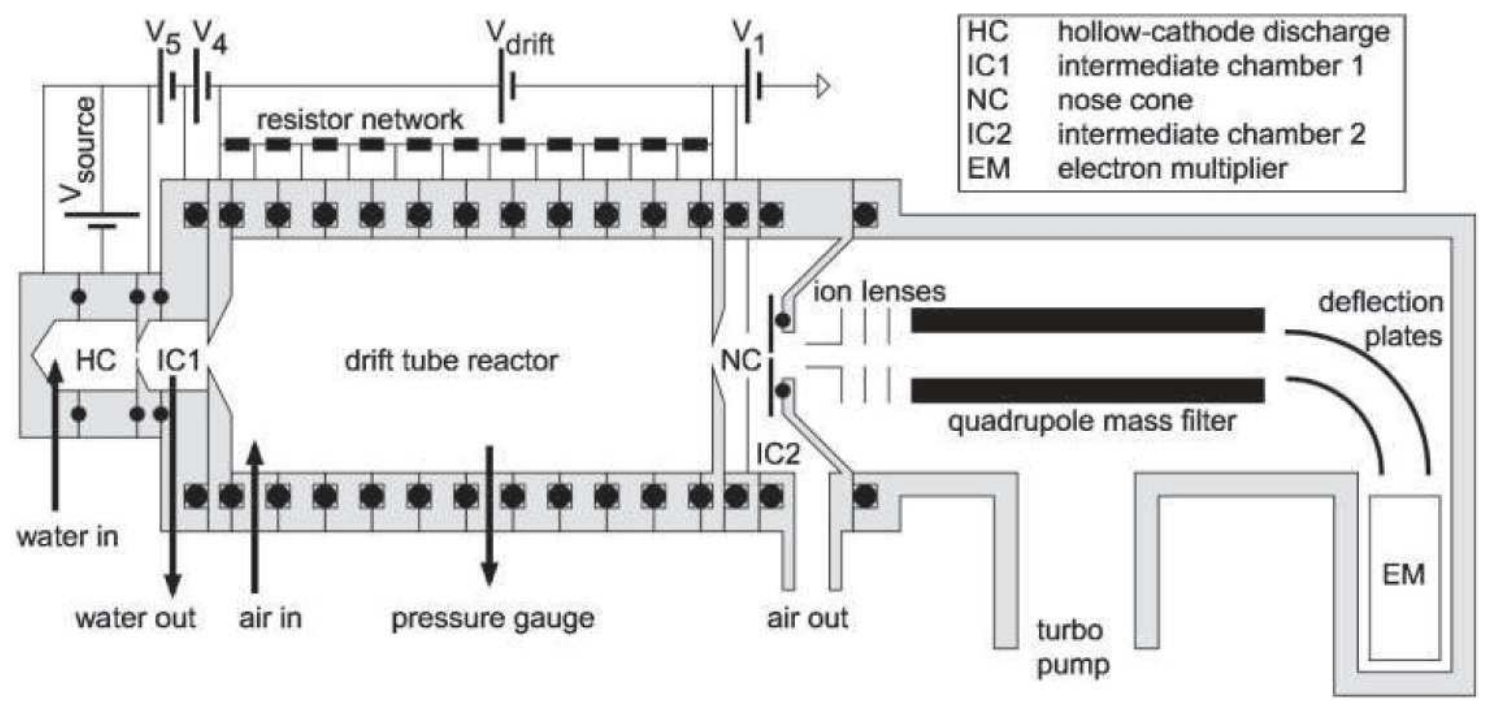

Figure 2 Schematic drawing of the Proton-Transfer-Reaction Mass Spectrometry (PTR-MS) [21]

Besides the limitation on measuring odorous compounds with lower proton affinities and with similar molecular weights, there are also some odorous compounds for which the proton affinity is close to water. The presence of water from the sampling air and the ion source may enhance the influence of the back reaction between $\mathrm{RH}^{+}$and water (Reaction 10). Consequently, the concentration is underestimated. Therefore, it is necessary to investigate the humidity dependence of the PTR-MS response towards those compounds and correct the measured concentration to the real value according to this humidity dependence. In this study, $\mathrm{H}_{2} \mathrm{~S}$ has a proton affinity of $712 \mathrm{~kJ} \mathrm{~mol}^{-1}$ close to water $\left(691 \mathrm{~kJ} \mathrm{~mol}^{-1}\right)$. The humidity dependence of $\mathrm{H}_{2} \mathrm{~S}$ was investigated and a method for correction of the signal was presented [23]. In Figure 3, the expected concentration of a gas standard $\left(\mathrm{C}_{\mathrm{std}}\right)$ relative to the observed concentration $\left(\mathrm{C}_{\mathrm{obs}}\right)$ of $\mathrm{H}_{2} \mathrm{~S}$ was related to the humidity of the sample air (monohydrate cluster $\left(\mathrm{H}_{3} \mathrm{O}^{+} \cdot \mathrm{H}_{2} \mathrm{O}, \mathrm{m} / \mathrm{z}\right.$ 37) relative to the $\mathrm{H}_{3} \mathrm{O}^{+}$(measured as the $\mathrm{O}^{18}$ isotope, $\mathrm{m} / \mathrm{z}$ 19). Furthermore, formaldehyde was produced as a by-product from photocatalytic oxidation of reduced sulphur compounds (Paper II), and a humidity dependence of the PTR-MS response towards formaldehyde is also necessary to quantify its concentration.

$\mathrm{RH}^{+}+\mathrm{H}_{2} \mathrm{O} \rightarrow \mathrm{R}+\mathrm{H}_{3} \mathrm{O}^{+}$

Reaction 10 


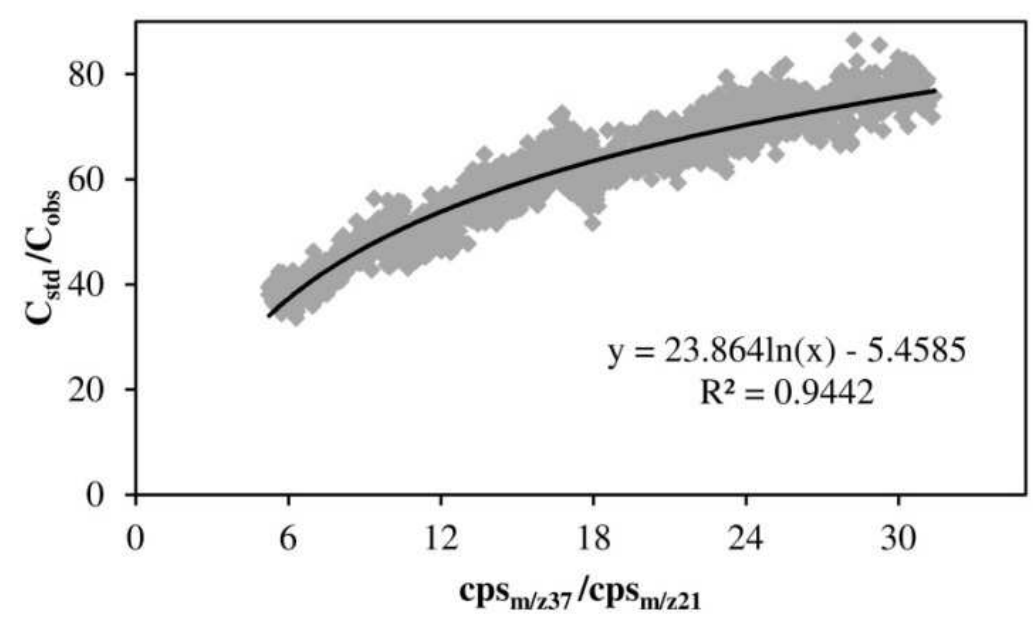

Figure 3 Relative response of PTR-MS to $\mathrm{H}_{2} \mathrm{~S}$ as a function of humidity at concentration of $740 \mathrm{ppbv}\left(\mathrm{C}_{\text {std }}\right)$ expressed as the concentration of the diluted gas from the standard gas cylinder by filtered compressed air to the observed concentration $\left(\mathrm{C}_{\mathrm{obs}}\right)$. The full line represents the empirical equation fitted to the data. (cps - count per second) (Paper VI)

The cluster ions $\left(\mathrm{H}_{3} \mathrm{O}^{+} \cdot\left(\mathrm{H}_{2} \mathrm{O}\right)_{\mathrm{n}}\right)$ can also react with odorous compounds, so they may cause interferences of the sensitivity during the measurement by PTR-MS. However, in these studies the total water cluster was all kept below 5\%, and the primary ion was not affected. The formation of the cluster ions in the drift tube reactor is related to the drift tube voltage and the parameter $\mathrm{E} / \mathrm{N}$ value in units of Townsend $\left(1 \mathrm{Td}=10^{-17} \mathrm{~V} \mathrm{~cm}{ }^{2}\right)$, where $\mathrm{E}$ is the electric field and $\mathrm{N}$ is the total molecule numbers in the drift tube. Generally, $\mathrm{H}_{3} \mathrm{O}^{+}$ions in PTR-MS dominate a drift voltage of $600 \mathrm{~V}(100 \mathrm{Td}), \mathrm{H}_{3} \mathrm{O}^{+} \cdot \mathrm{H}_{2} \mathrm{O}$ ions dominate between 350 and $600 \mathrm{~V}(60-100 \mathrm{Td})$, and $\mathrm{H}_{3} \mathrm{O}^{+}\left(\mathrm{H}_{2} \mathrm{O}\right)_{2}$ ions dominate below $350 \mathrm{~V}(60 \mathrm{Td})$ [21].

In addition, the sensitivity can also be affected by the transmission efficiencies for $\mathrm{RH}^{+}$and $\mathrm{H}_{3} \mathrm{O}^{+}$ions. The transmission efficiencies are determined by 1) extraction efficiency of ions from the drift tube reactor into the mass spectrometry, 2) detection efficiency of each mass in the electron multiplier. The transmission efficiency can be estimated by a standard gas covering a relevant $\mathrm{m} / \mathrm{z}$ range. In this work, transmission efficiency was checked regularly during the measurement period with a mixture of 14 aromatic compounds between $\mathrm{m} / \mathrm{z} 79$ and $\mathrm{m} / \mathrm{z} 181$ in this project. The concentrations of odorous compounds were calculated based on proton transfer rate constants as described by Feilberg et al. [23]. 


\subsubsection{Gas Chromatography with Mass Spectrometry (GC/MS)}

Gas Chromatography with Mass Spectrometry (GC/MS) is a very common method for measuring the odorous compounds, and is used in a combination with adsorbent tubes in this $\mathrm{PhD}$-project. Odorous compounds that trapped on the adsorbent tubes are thermally desorbed, separated by gas chromatography and then detected in a mass spectrometer. The NIST database is normally used for identification of compounds, and the possible compound was considered to be identified when the match rate was higher than $90 \%$ and when the abundance of the characteristic ions were in good agreement with the library spectrum. GC/MS is an offline method with a limited sample capacity, since a typical GC/MS run takes 45 minutes. Some compounds with high reactivity might be oxidised or converted to other compounds during sampling and analysis based on solid adsorbent tubes [5]. The main advantage of GC/MS is the chromatographic separation prior to the MS detection. GC/MS was used in Paper II for assisting PTR-MS in investigating the by-products from the photocatalytic reactor.

\subsubsection{Gas Chromatography with Sulphur Chemiluminescence Detector (GC/SCD)}

Gas chromatography with sulphur chemiluminescence detector (GC/SCD) is a specific detector for measuring the sulphur-containing odorous compounds, e.g. $\mathrm{H}_{2} \mathrm{~S}, \mathrm{SO}_{2}$, DMS, DMDS and DMTS. After the separation by GC, sulphur compounds are combusted $\left(>1800{ }^{\circ} \mathrm{C}\right)$ in a furnace in SCD by a hydrogen/air burner and converted to sulphur monoxide (SO) (Reaction 11). SO can further react with ozone $\left(\mathrm{O}_{3}\right)$ in a chemiluminescence reaction to form an excited state of $\mathrm{SO}_{2}{ }^{*}$ which can be detected by a photomultiplier (reaction 12). The advantage of GC/SCD is that 1) the same amount of sulphur gives the same response independently of the molecular structure (equimolarity), so if the retention time is known, the sulphur compounds can be quantified, 2) the detection limit of $\mathrm{GC} / \mathrm{SCD}$ is also low (typically 2-10 ppb). To investigate the by-products from the wet scrubber combined with a peroxone process on removal of reduced sulphur compounds, gas samples were collected form the gas outlet from the scrubber into the Tedlar bags, and directly analysed by GC/SCD (Paper VI).

$\mathrm{S}$-compound $+\mathrm{O} \rightarrow \mathrm{SO}+$ Other Products

Reaction 11

$\mathrm{SO}+\mathrm{O}_{3} \rightarrow \mathrm{SO}_{2} *+\mathrm{O}_{2}+\mathrm{h}(300-400 \mathrm{~nm})$

Reaction 12

\subsection{Liquid analysis}

During the process of the gas purification in the $\mathrm{PhD}$-project, liquid analyses were also carried out for understanding the reaction processes in liquid phase. 


\subsubsection{Dissolved $\mathrm{O}_{3}$}

So far, several methods have been used to measure the dissolved ozone in the solution: UV spectrophotometric method, DPD (N,N-diethyl-p-phenylenediamine) colourimetric method, indigo colourimetric method, iodometric titration method, oxidation/reduction potential (ORP), and dissolved ozone sensor [140-151]. However, no single method or standard unit of the measurement is consistently used by the scientific community or industry, which makes it difficult to compare and standardise dissolved ozone measurements. Furthermore, there is a gap on monitoring the ozone decay in e.g. $\mathrm{H}_{2} \mathrm{O}_{2}$ solution while removing the odorous compounds in the air. Therefore, six methods for measuring the dissolved ozone were evaluated with the aim of finding and verifying a time-resolved and accurate method to measure the dissolved ozone in low concentrations $(<20 \mu \mathrm{M})$. The details of the six methods were:

1) UV spectrophotometric method [142]. Dissolved ozone in pure water can be directly measured by UVVisible spectrophotometer, since ozone can be absorbed by ultraviolet light at $258 \mathrm{~nm}$ with an extinction coefficient of $2950 \mathrm{M}^{-1} \mathrm{~cm}^{-1}$. Several studies have utilised the method to evaluate the decomposition of ozone by UV/vis adsorption $[143,144,150]$. The method is only suitable for relatively pure solutions with insignificant interference from other compounds.

2) Indigo colourimetric method $[142,152]$. The advantage of the indigo colourimetric method is that it is sensitive, precise, specific and easy to handle. The principle is that ozone can rapidly decolourise indigo under acidic condition. The decrease in absorbance is linear with increasing concentration of ozone. The proportionality constant at $600 \mathrm{~nm}$ is $0.42 \pm 0.01 \mathrm{~cm}^{-1} \mathrm{mg}^{-1} \mathrm{~L}^{-1}(\Delta \mathrm{E}=20000 / \mathrm{M} \cdot \mathrm{cm}) \cdot \mathrm{H}_{2} \mathrm{O}_{2}$ could also be the interference. However, the decolourisation of indigo by $\mathrm{H}_{2} \mathrm{O}_{2}$ is much slower than that by ozone, and $\mathrm{H}_{2} \mathrm{O}_{2}$ may not affect the measurement of $\mathrm{O}_{3}$ if analysing the ozonated solution within 6 hours. This method is the most popular method for measuring dissolved ozone in recent researches [149, 153-157].

3) DPD colourimetric method [141, 145]. The DPD colourimetric method is normally used to measure the chlorine residual and $\mathrm{H}_{2} \mathrm{O}_{2}$ concentration. For ozone detection, the principle is that ozone reacts with DPD to form a red-violet dye in weakly acidic solution which can be determined photometrically (550 $\mathrm{nm}$ ) with an absorption coefficient of $0.225 \mathrm{~cm}^{-1} \mathrm{mg}^{-1} \mathrm{~L}$ for aqueous ozone. The DPD method is fast and simple. However, $\mathrm{H}_{2} \mathrm{O}_{2}$ will be interference when the concentration of $\mathrm{H}_{2} \mathrm{O}_{2}$ is higher than $1.5 \mu \mathrm{M}$, because it may bleach the red-violet colour.

4) Iodometric titration method $[142,158,159]$. This method is also primarily used to measure chlorine residuals and has only been used to measure dissolved ozone in solutions in early research. In the ozonated solution, ozone can react with potassium iodide (KI) at $\mathrm{pH} \leq 8$ to form free iodine (Reaction 
13). The free iodine can be titrated by a standard solution of sodium thiosulphate with starch as the indicator due to the blue colour formed by free iodine and starch (Reaction 14).

$2 \mathrm{KI}+\mathrm{H}_{2} \mathrm{O}+\mathrm{O}_{3} \rightarrow 2 \mathrm{KOH}+\mathrm{I}_{2}+\mathrm{O}_{2}$

Reaction 13

$\mathrm{I}_{2}+2 \mathrm{Na}_{2} \mathrm{~S}_{2} \mathrm{O}_{3} \rightarrow 2 \mathrm{NaI}+\mathrm{Na}_{2} \mathrm{~S}_{4} \mathrm{O}_{6}$

Reaction 14

5) Oxidation/reduction potential (ORP) [151]. Redox potential is an indirect method for measuring the dissolved ozone. The method does not allow direct quantification of ozone and the results are given in $\mathrm{mV}$, according to the oxidising property of ozone. Therefore, it is not ozone specific. If the redox potential is solely governed by ozone, the method can in principle be used for ozone measurement by proper calibration e.g. with a reference method.

6) Dissolved ozone sensor $[147,155]$. The dissolved ozone sensor is an on-line and electrochemical device for monitoring ozone concentration at low level $(\mu \mathrm{M})$. A gas permeable polymer membrane is used to separate the heart of the sensor from the sample, and the diffusion rate of ozone through the membrane is proportional to the partial pressure of ozone in the sample. The concentration in $\mu \mathrm{g} \mathrm{L}^{-1}$ can be directly recorded by data log.

\subsubsection{Sulphate analysis $\left(\mathrm{SO}_{4}{ }^{2-}\right)$}

Sulphate concentration was measured in the test of the wet scrubber for the calculation of the $\mathrm{S}$ balance in the study (Paper VI). The principle is that sulphate ions can react with barium ions to form barium sulphate particles. The resulting turbidity is measured by spectrophotometry at $445 \mathrm{~nm}$ (turbidimetric method). It is a requirement that the solution does not contain any particles and sample filtration may therefore be necessary. The method is analogous to APHA 4500-SO ${ }_{4}^{2-} \mathrm{E}[142]$. 


\section{Description of the reactors used in the study}

Several reactors combined with AOPs were designed based on the existing literature on removal of reduced sulphur compounds. The strengths and weaknesses relevant to the study are discussed.

\subsection{Photocatalytic reactor}

Three types of photocatalytic reactors are often applied, which are: plate type, honeycomb type and annular type reactors (Figure 4) [160]. The plate type reactor is the simplest, and it has been widely used on removal of odorous compounds due to the low pressure drop across the reactor [161-164]. However, a long residence time has to be maintained in order to obtain a high removal, presumably because the average distance from the gas phase to the photoactive surface is relatively long. It has previously been found that the mass transfer is not limited in the honeycomb reactor [165]. However, due to the typically short residence time, the removal performance is restrained by the capability of the adsorption and the reaction rate between the odorous compounds with oxidants generated on the surface of the $\mathrm{TiO}_{2}$ filter [160]. The annular type reactor is the second-most applied photocatalytic reactor in research, and the removal of reduced sulphur compounds in these reactors has been reported to be relatively high $[10,12,166]$. However, the mass transfer is a bottleneck in the annular reactor. Turbulence of the air is a necessity for maximising the mass transfer on the $\mathrm{TiO}_{2}$ surface, which may increase the pressure drop in the system, and due to the resulting economic limitation, it is difficult to use in the livestock and industrial facilities. 
(a)

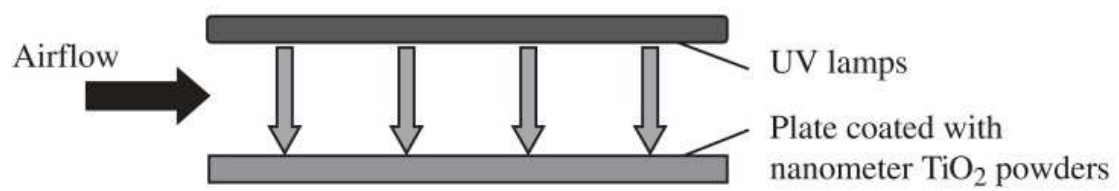

(b)

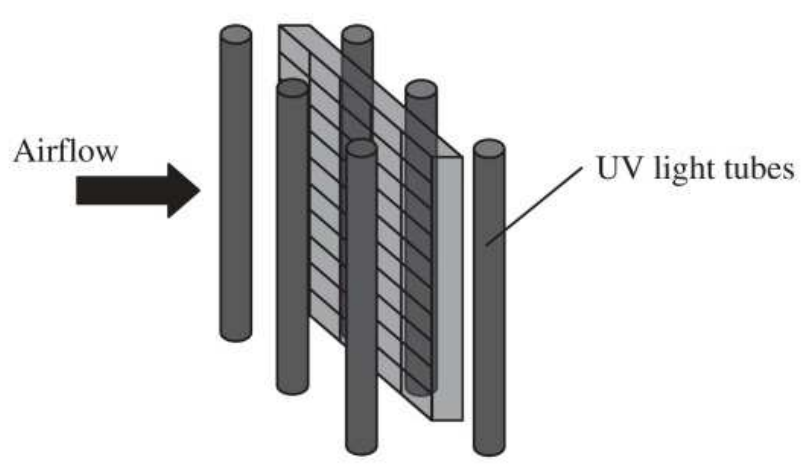

(c)

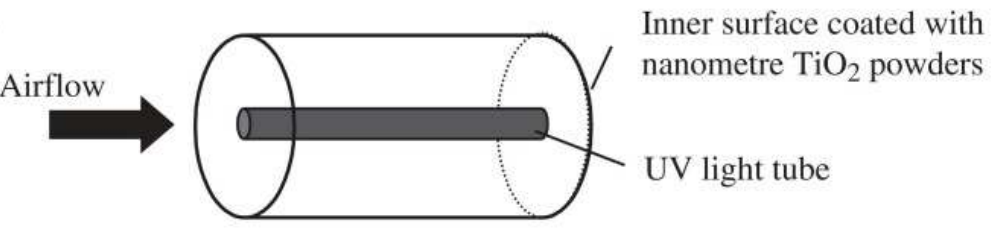

Figure 4 Schematics of three types of photocatalytic reactor (a) plate type, (b) honeycomb type, (c) annular type [160]

The honeycomb-type photocatalytic reactor was selected to assess the removal of odorous compounds in this $\mathrm{PhD}$-project. In most studies, photocatalytic oxidation of reduced sulphur compounds was carried out at ppm level (ten to hundreds ppmv) $[11,12,113,162,166,167]$ for relatively long residence time (from several seconds to several minutes) for adsorbing more contaminants on the $\mathrm{TiO}_{2}$ surface $[10-12,113,162,166,168]$. However, in the practical situation such as in livestock and industrial facilities, the concentrations of contaminants are in the range from sub-ppb to ppb level, and the air velocity is usually high so the residence time becomes short $(<0.5 \mathrm{~s})$ if realistically sized filters are to be used [23, 32, 101]. Furthermore, photocatalytic oxidation is not suitable for treating contaminated air with high concentrations of sulphur compounds, because their by-products, such as sulphate $\left(\mathrm{SO}_{4}{ }^{2-}\right)$ or methane sulphonic acid, may bind to the surface of the photocatalyst and cause the deactivation of the photocatalyst [11]. However, Demeestere et al. reported that low concentrations of DMS (<3 ppmv) would not deactivate the $\mathrm{TiO}_{2}$, and relative humidity between $18.9 \%$ and $52.9 \%$ would not affect the removal of DMS either [11]. The photocatalysis technology could therefore be a viable solution for the abatement of reduced sulphur compounds emissions as a post-stage treatment after air 
scrubbers. Paper I - III demonstrated that honeycomb type photocatalytic reactor was a feasible reactor to remove reduced sulphur compounds in relatively short residence time $(<0.30 \mathrm{~s})$ and low concentrations $(20$ 300 ppbv).

\subsection{Bubble reactor}

In most previous studies [169-171], a bubble column reactor was used as a wet scrubber coupled with AOPs. Therefore, a bubble reactor (Figure 5) coupled with peroxone process was tested in this $\mathrm{PhD}$-project as a preexperiment in order to assess the effect of the wet scrubber on removal of DMS (Paper V). This reactor has demonstrated high removal efficiency on DMS. In order to improve the performance of such reactor, the following issues can be considered: 1) reducing the cost of establishment to apply the bubble reactor in livestock and industrial facilities due to the economic limitation, 2) possibly increasing the contact area to improve the mass transfer in the bubble reactor and to avoid the high pressure drop, 3) large scale of bubble reactor would be required in the situation with high air flow rate.

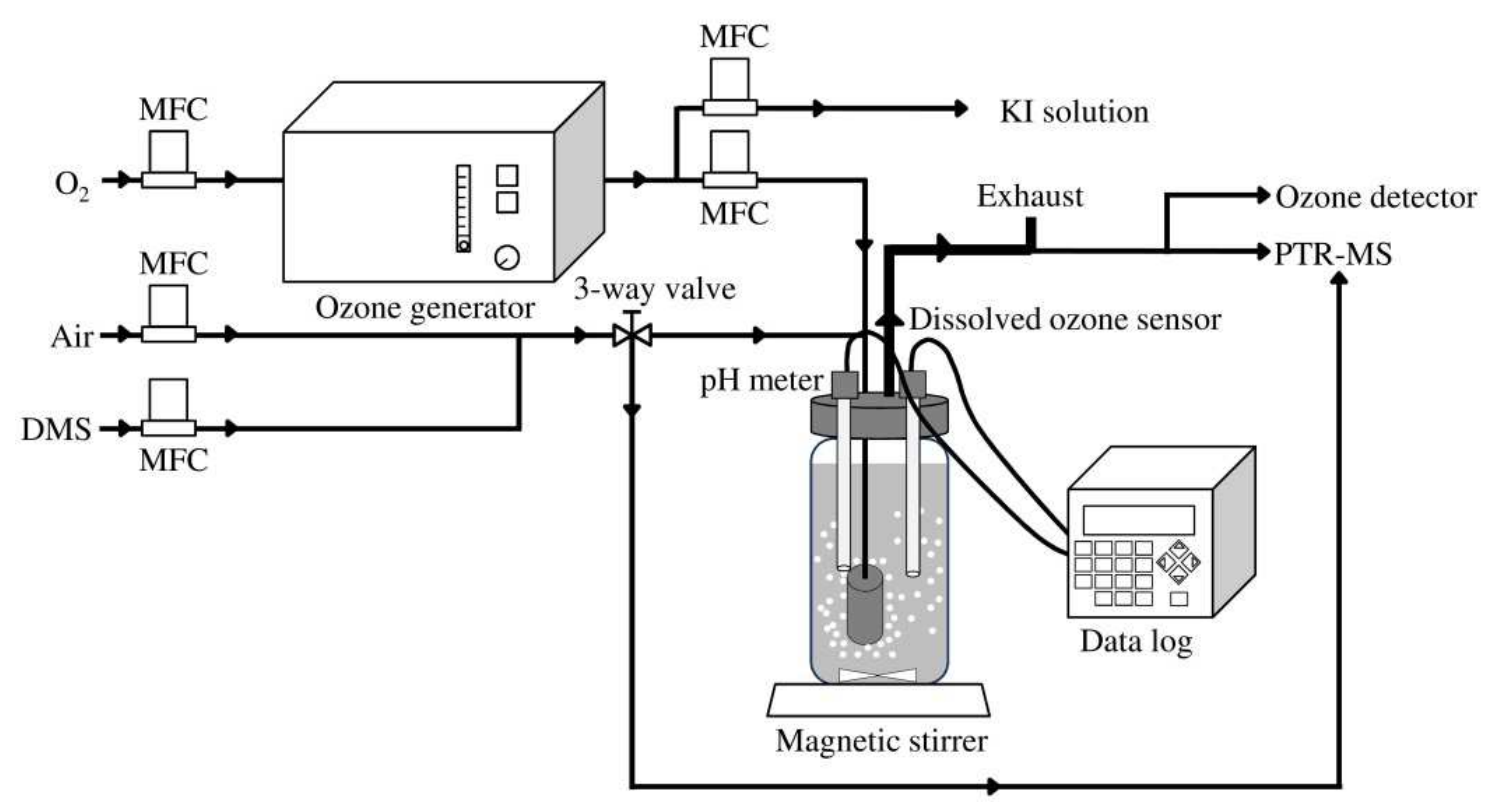

Figure 5 Schematic drawing of bubble reactor (MFC - mass flow controller, DMS - dimethyl sulphide, PTR-MS - proton-transfer-reaction mass spectrometry) (Paper IV)

\subsection{Wet scrubber}

Several setups of wet scrubbers have been reported. Biard et al. tested a wet compact scrubber packed with wire mesh packing structure and coupled with a peroxone process $[156,172]$. In their system, $\mathrm{O}_{3}$ was first dissolved 
into tap water, and then mixed with the $\mathrm{H}_{2} \mathrm{O}_{2}$ solution $(10.42 \mathrm{mM})$ right before it was sprayed into the wet scrubber. The mass transfer of the target compound (DMDS) was enhanced compared with the spray solution without $\mathrm{H}_{2} \mathrm{O}_{2}$ in the short residence time. However, the removal efficiency of DMDS was increased from $16 \%$ to 34\%. Larson and Adams (1999) presented another wet scrubber setup coupled with the peroxone process. They used 316 stainless steel Pro-Pak as packing material, and directly injected $\mathrm{O}_{3}$ in the concentration of $1.9 \times 10^{3}$ ppmv into the air before the air flow passed through the wet scrubber and they used concentration of $\mathrm{H}_{2} \mathrm{O}_{2}(0.74$ $\mathrm{mM}$ ) in the spray solution. With this setup, both removal efficiency and mass transfer of toluene, benzene and xylene were all enhanced when $\mathrm{pH}$ of trickling solution was increased [154]. Therefore, direct injection of $\mathrm{O}_{3}$ was used in this $\mathrm{PhD}$ project on assessing the removal of reduced sulphur compounds in the packed-bed wet scrubber (Figure 6) (Paper VI).

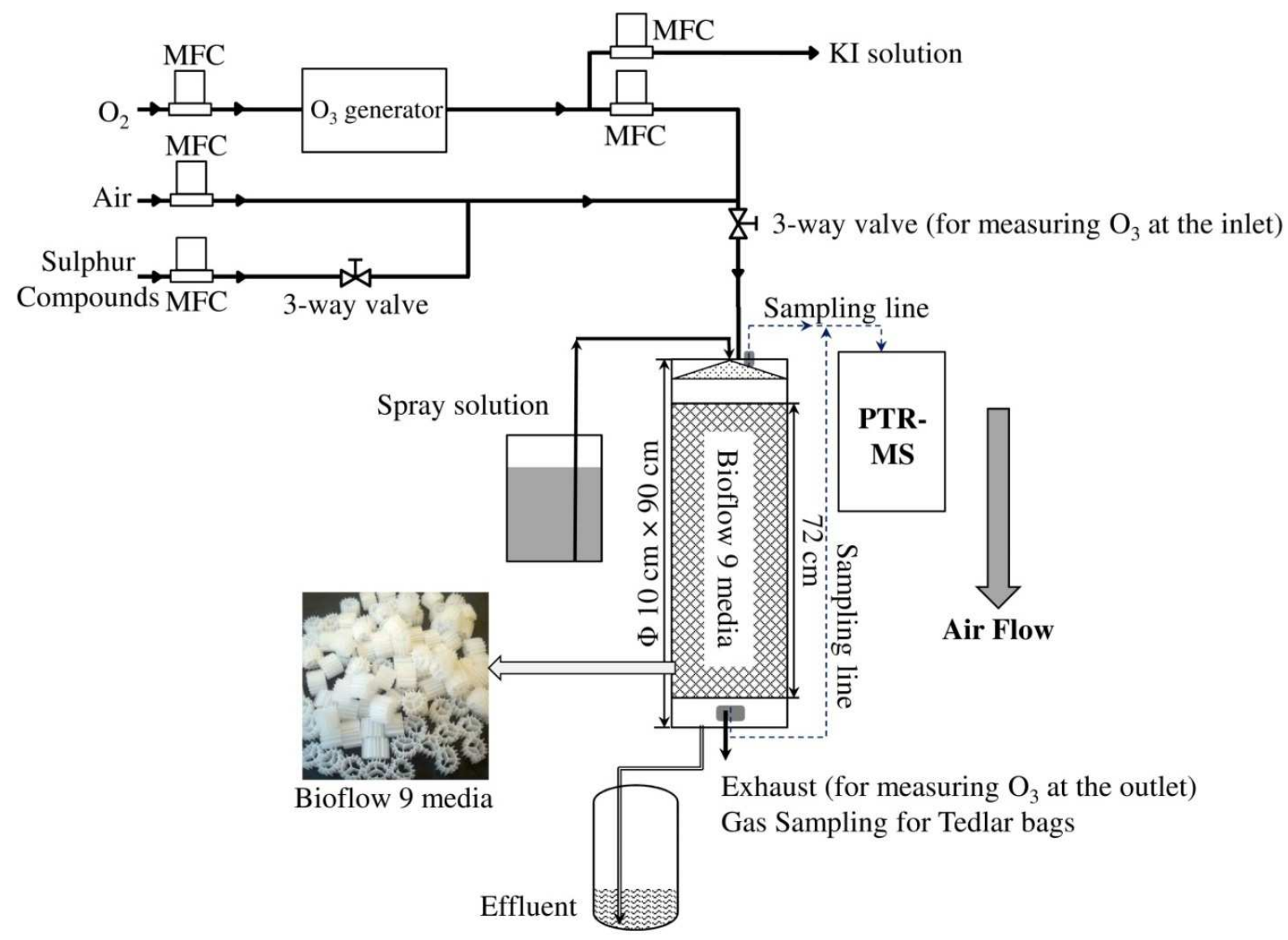

Figure 6 Schematic drawing of wet scrubber combined with peroxone process (MFC - mass flow controller, PTR-MS - proton-transfer-reaction mass spectrometry) (Paper VI) 


\section{General discussion of Paper I - VI}

The experimental of the present $\mathrm{PhD}$-thesis is presented in two sub-section: the assessment of photocatalytic reactor (Paper I - III), and the investigation of the wet scrubber combined with peroxone process (Paper IV - VI). The six papers can be seen in their full length in the appendix. In the following section, the main results from paper I - VI will be summarised and discussed.

\subsection{Photocatalysis (Paper I - III)}

In most of the studies on assessing the photocatalytic reactor, the air flow rates were low with a relatively long residence time [101]. However, in the practical situation such as in livestock and industrial facilities, the concentrations of contaminants are in the range from sub-ppbv to ppbv level, and the air velocity is usually high so that the residence time becomes short $(<0.5 \mathrm{~s})$ [23, 32, 101]. Further studies of photocatalytic oxidation under more realistic conditions are required. A bench-scale of honeycomb type monolith photocatalytic reactor (Figure 7) was tested in the laboratory (Paper I - II). The temperature and the relative humidity were relatively stable $\left(24.0 \pm 0.6{ }^{\circ} \mathrm{C}\right.$ and $\left.35-45 \%\right)$. Three reduced organic sulphur compounds were assessed, which were methanethiol (MT), dimethyl sulphide (DMS), and dimethyl disulphide (DMDS). Three tests were carried out in the reactor: 1) kinetic studies of the three sulphur compounds in the reactor at different UV intensities and air flow rates), 2) Influencing factors on the performance of photocatalytic reactor (initial concentration, UV intensity and air flow rate), and 3) investigation of by-products, their possible pathways and the risk assessment of the by-products of the three sulphur compounds. For experiment 1) and 2), MID mode of PTR-MS was used to monitor the single compounds at inlet and outlet of the reactor. For experiment 3), both PTR-MS and GC-MS were used to investigate the by-products of the three reduced sulphur compounds, and a full scan mode was used in PTR-MS. 


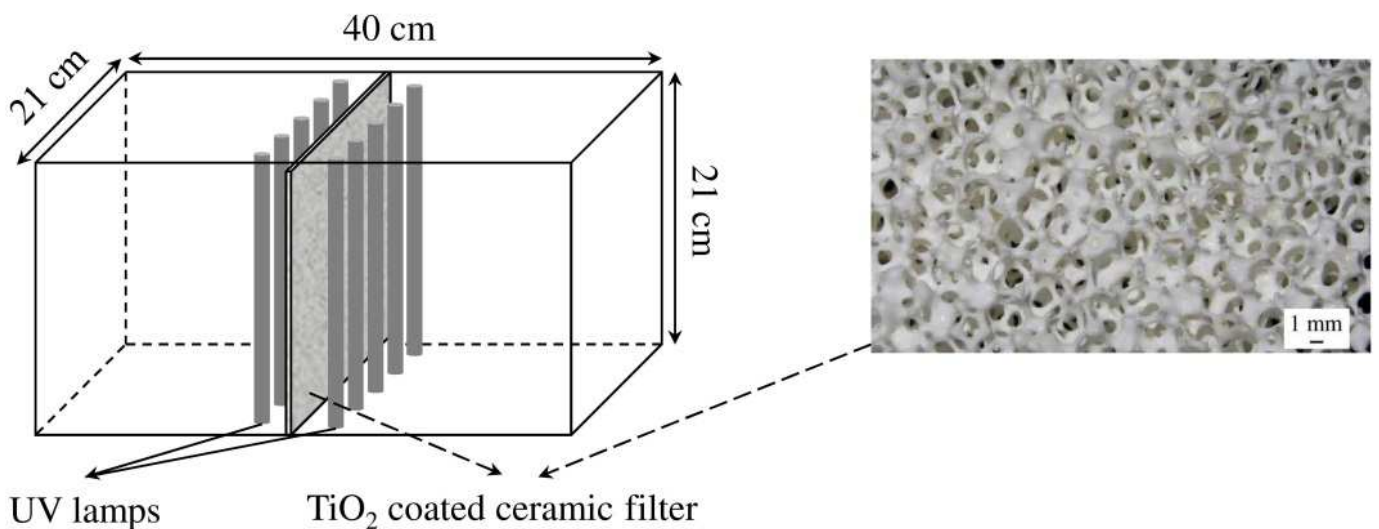

Figure 7 Schematics of the photocatalytic oxidation reactor in bench scale and the photo of the $\mathrm{TiO}_{2}$ coated ceramic filter

The Langmuir-Hinshelwood model was used for the kinetic studies (Figure 8) and the intercepts of each trend line represent the Langmuir adsorption constants $(\mathrm{K})$, and $\mathrm{K}_{\mathrm{DMDS}}>\mathrm{K}_{\mathrm{DMS}}>\mathrm{K}_{\mathrm{MT}}$ which is in agreement with the different saturated vapour pressure (MT > DMS > DMDS). Furthermore, due to the accurate and time-resolved measurement by PTR-MS, the uncertainties of the kinetic studies in Langmuir-Hinshelwood model were less than $20 \%$ in most cases. On the test of air flow rate dependence, both removals of MT and DMS were not significantly influenced by the air flow rate. In contrast, DMDS was much more sensitive to the higher air flow rates $\left(>216.0 \mathrm{~L} \mathrm{~min}^{-1}\right)$.

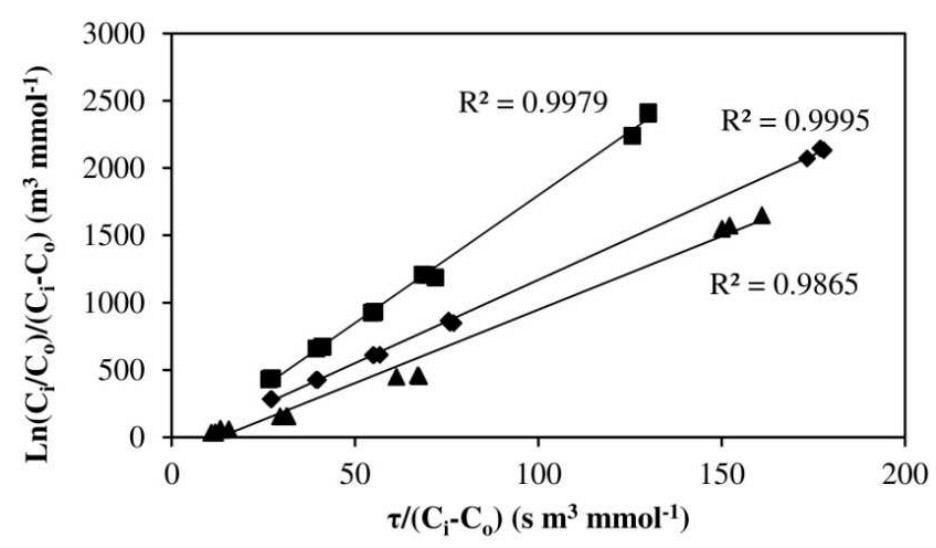

Figure 8 Langmuir-Hinshelwood kinetic model fitting results in the honeycomb-type photocatalytic reactor for the reduced organic sulphur compounds at the same UV intensity $\left(12.7 \mathrm{~mW} \mathrm{~cm}^{-2}\right): \bullet-$ methanethiol, dimethyl sulphide, $\mathbf{\Delta}$ - dimethyl disulphide (Paper I) 
Removal efficiency of MT and DMS was not significantly affected at different initial concentrations at the same UV intensity or the same air flow rate, and the removal efficiency was only significantly lower than at full UV intensity when only 3 out of $10 \mathrm{UV}$ lamps was used in the photocatalytic reactor $(P<0.001)$. Removal efficiency of DMDS was significantly decreased when the number of UV lamps was reduced $(P<0.01)$ or the air flow increased. Furthermore, removal efficiency of DMDS was the lowest among the three sulphur compounds at the same condition. Possibly it is related to the fact that 1) DMDS has a lower negative atomic charge on each of the sulphur atoms (-0.177 e) compared to the single sulphur atom in DMS (-0.300 e), so DMS could react faster with the positively charged hole [173-175], 2) the redox potential of DMS was $1.79 \mathrm{~V}$ versus a saturated calomel electrode (SCE) in $\mathrm{CH}_{3} \mathrm{CN}$, which is higher than that of DMDS (1.15 V). Although it was in a different matrix, it could also indicate that the electron transfer of DMS is higher than that of DMDS [10], 3) singlet oxygen (Reaction 4) could add on the sulphide, which leads to the formation of thiosulfinate and thiosulfonate. However, this reaction occurs less readily for disulphides compared to sulphides [173]. Therefore, DMDS is less reactive.

PTR-MS has significantly improved the identification of the by-products of the three sulphur compounds with assistance of GC/MS. Formations of the by-products could be traced by adjusting initial concentrations of the odorous compounds, and the concentration of the $\mathrm{m} / \mathrm{z}$ corresponding to the by-products increased with the increase of initial concentration. Figure 9 shows an example for DMS. Some specific by-products of photocatalytic degradation of each sulphur compound are suggested for the first time in this study mainly according to PTR-MS: MT, S-methyl methanethiosulfinate and S-methyl methanethiosulfonate were formed from photocatalytic degradation degradation of both DMS and DMDS. The photocatalytic degradation of DMDS also tentatively produce methylthiomethanol, S-methyl thioformate for DMS, and dimethyl trisulphide and methyl(methylthio)methyl disulphide. Moreover, an odor activity value (OAV) was introduced to assess the risk to the environment of these by-products, which is the concentration of each by-product $\left(\mathrm{C}_{\text {by-product }}\right)$ divided by the recommended odor threshold value of each by-product $\left(\mathrm{OTV}_{\text {by-product }}\right)$ (Table 1). It was concluded that photocatalytic degradation of MT and DMDS resulted in less environmental impact, while photocatalytic degradation of DMS did not change the environmental impact significantly due to the high production of MT for which the odour threshold value is very low $(0.07 \mathrm{ppbv})$. Furthermore, it was found that formaldehyde was produced from the photocatalytic oxidation of all of the three reduced sulphur compounds, and formaldehyde is a carcinogen. However, based on the reaction rate, both formaldehyde and MT can react with OH. radicals in relative high reaction rate. It is suggested as a possible solution to connect one or more additional $\mathrm{TiO}_{2}$ filter in series or increase the residence time of the target odorous compounds to remove MT and formaldehyde produced. 


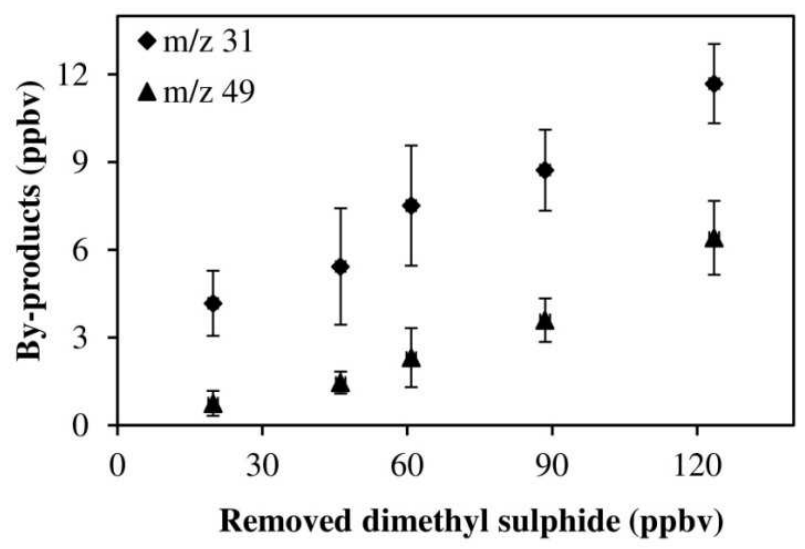

Figure 9 Relations between removed dimethyl sulphide and the production of their by-products measured by PTR-MS with different initial concentrations

A pilot-scale of the honeycomb monolith photocatalytic reactor (Figure 10) was tested in the laboratory with three $\mathrm{TiO}_{2}$ filers installed (Paper III). The processing condition applied in the pilot-scale reactor was closer to the livestock facilities. Eight typical odorous compounds found from livestock facilities were tested with similar concentration, which were methanethiol (MT), dimethyl sulphide (DMS) and dimethyl disulphide (DMDS)), one alcohol (1-butanol), and four volatile fatty acids (VFAs) (acetic acid (AA), propionic acid (PA), 1-butanoic acid (BA) and 1-valeric acid (1-VA). The removal efficiency was tested at high air flow rate (up to $1000 \mathrm{~m}^{3} \mathrm{~h}^{-1}$ ). Removal efficiency above $80 \%$ was observed at a lower flow rate $\left(<200 \mathrm{~m}^{3} \mathrm{~h}^{-1}\right)$ and low initial concentrations (in ppbv level) in all cases. Removal efficiencies were significantly reduced when the flow rate was increased above $500 \mathrm{~m}^{3} \mathrm{~h}^{-1}(P<0.05)$, but were not significantly affected by adjusting the relative humidity within the range of $40 \%$ to $80 \%$. Therefore, humidification of the air would not improve the removal efficiencies of odorous compounds from livestock facilities and the highest relative humidity in livestock facilities would not be able to deactivate the $\mathrm{TiO}_{2}$ filter. Cutting the number of UV lamps by $50 \%$ did not alter the removal efficiencies of the volatile odorous compounds significantly. In addition, removal of $\mathrm{H}_{2} \mathrm{~S}$ was also tested, but this odorant could not be effectively removed. It is suggested to be improved by either reducing the high moisture [176] or changing the characteristic of $\mathrm{TiO}_{2}$ filter, such as doping other metal or catalysts on $\mathrm{TiO}_{2}[115,177]$. 


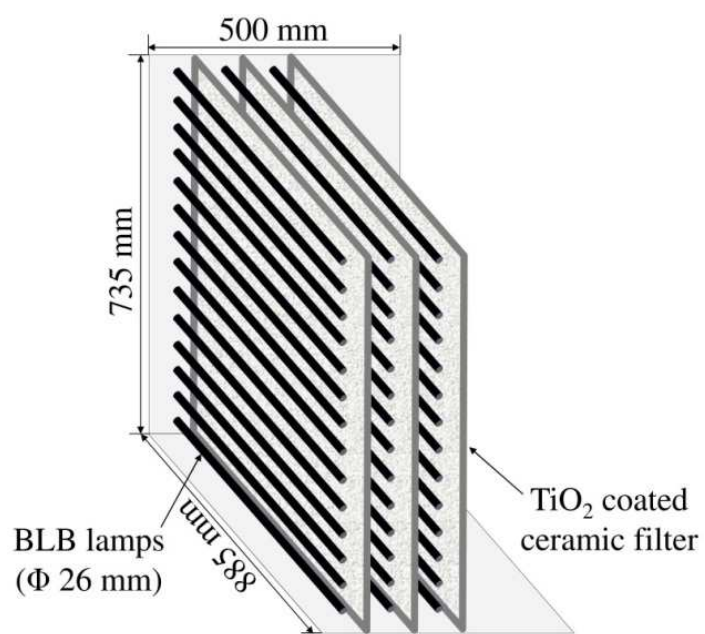

Figure 10 Schematics of the photocatalytic oxidation reactor in pilot scale

\subsection{Peroxone process (Paper IV - VI)}

Six methods for measuring the dissolved ozone were compared in the present $\mathrm{PhD}$-project, and a dissolved ozone sensor was found as the most accurate and time-resolved measurement (Paper IV). Furthermore, the dissolved ozone sensor was used on monitoring the ozone concentration in a bubbled reactor (Figure 5), at the meantime PTR-MS was used for monitoring the removal of DMS in the bubbled reactor coupled with peroxone process. The removal efficiency of DMS was above 90\% (Figure 11). Therefore, it is approved that peroxone reaction is a potential approach to purify the contaminated air (Paper V).

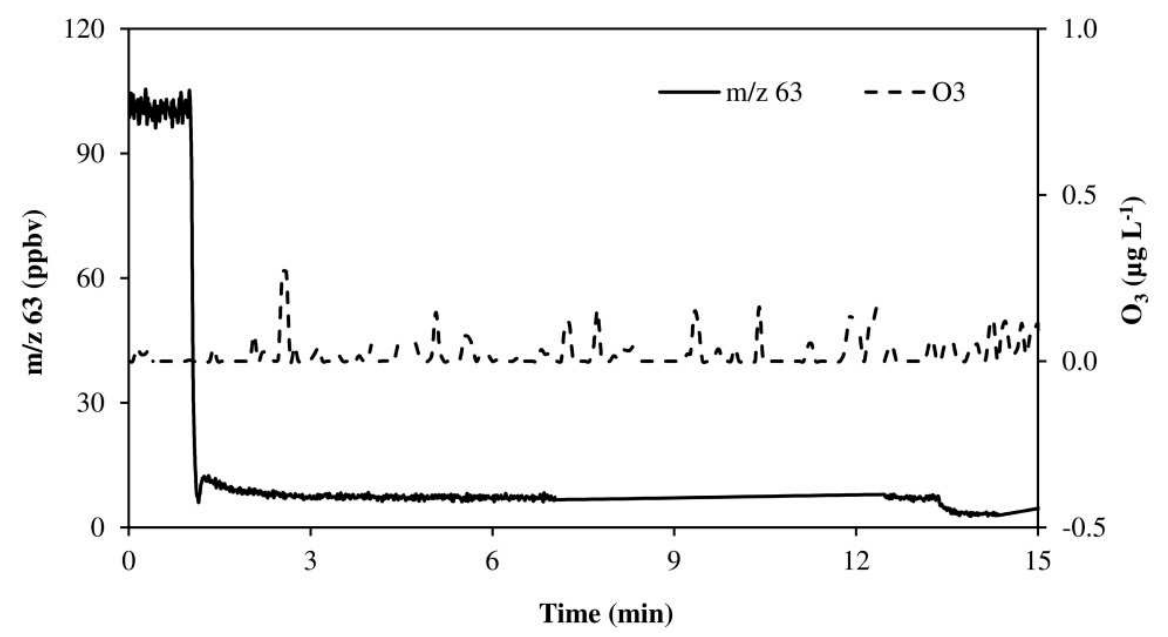

Figure 11 Removal of Dimethyl sulphide in the bubble reactor combined with peroxone processes and the concentration of dissolved ozone during the peroxone process (Paper V) 
According to the result from bubbled reactor, a packed-bed wet scrubber was designed, and an air flow rate resulting in an empty bed residence time of $7.8 \mathrm{~s}$ was applied with low initial concentration of $\mathrm{H}_{2} \mathrm{~S}$ ( $750 \mathrm{ppbv}$ ), DMS (110 ppbv) and MT (105 ppbv). Two types of materials was tested as packing materials, which were light expanded clay aggregate pellets $\left(\right.$ Leca $^{\circledR}$, Saint-Gobsin Weber A/S, Randers, Denmark) and plastic media (Bioflow9, $\Phi 9 \times 7 \mathrm{~mm}$, Hansa Engineering AB, Sweden). Both have been used in biofiltration, especially Leca ${ }^{\circledR}$ $[49,178]$. However, limited DMS was removed when using Leca ${ }^{\circledR}$ as packing materials, and possibly Leca ${ }^{\circledR}$ can react with $\mathrm{O}_{3}, \mathrm{H}_{2} \mathrm{O}_{2}$ and $\mathrm{OH} \cdot$ radicals. In contrast, Bioflow9 has large specific surface area $\left(800 \mathrm{~m}^{2} \mathrm{~m}^{-3}\right)$ and the surface is polyethylene, which does not react with both $\mathrm{O}_{3}$ and $\mathrm{H}_{2} \mathrm{O}_{2}$. Using Bioflow9, both $\mathrm{H}_{2} \mathrm{~S}$ and DMS could be effectively removed at high $\mathrm{O}_{3}$ flow injected (Figure 12). High pH value increases the removal of $\mathrm{H}_{2} \mathrm{~S}$. However, MT was not removed efficiently by this process (maximum 23.5\%; Figure 13), and possibly $\mathrm{O}_{3}$ does not react readily with MT, and the production of $\mathrm{OH}$ - radicals was not sufficient to degrade MT. It should be noted that $\mathrm{OH}$. radicals can also react with $\mathrm{O}_{3}$. In conclusion, $\mathrm{OH}$ - radical was not the principal reactant in removal of the sulphur compounds in the packed-bed wet scrubber tested in this work.
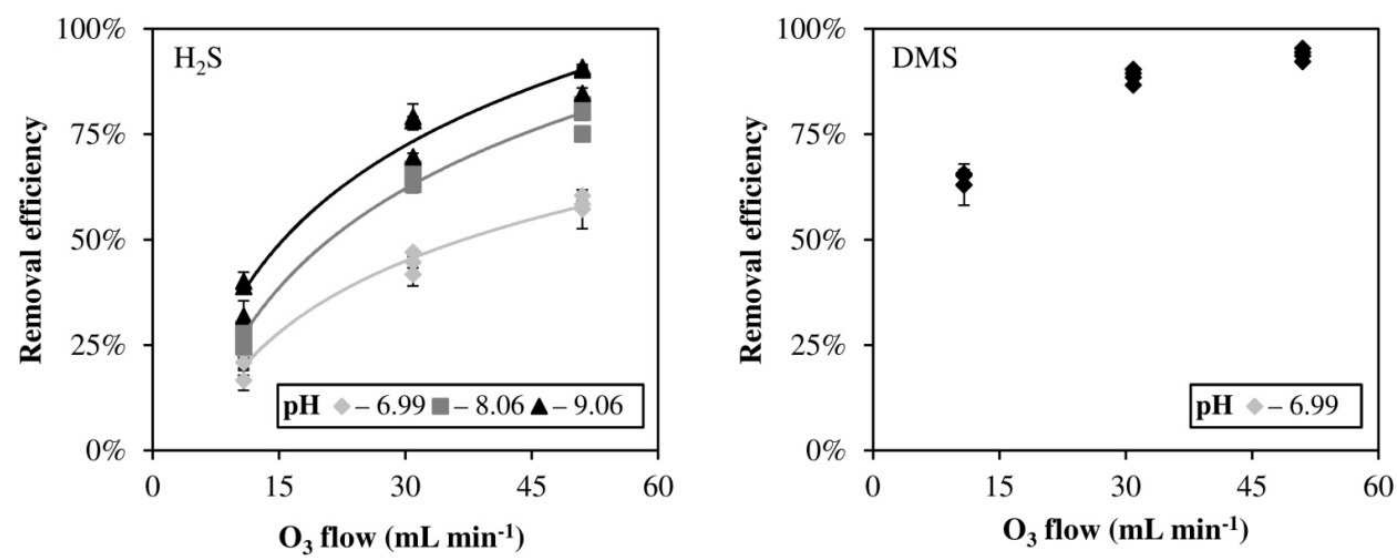

Figure 12 Removal efficiency of $\mathrm{H}_{2} \mathrm{~S}$ and dimethyl sulphide (DMS) in the packed-bed wet scrubber. Error bars represent the standard deviation from the replicates, and the trend lines in $\mathrm{H}_{2} \mathrm{~S}$ figure are followed a logarithmic regression 


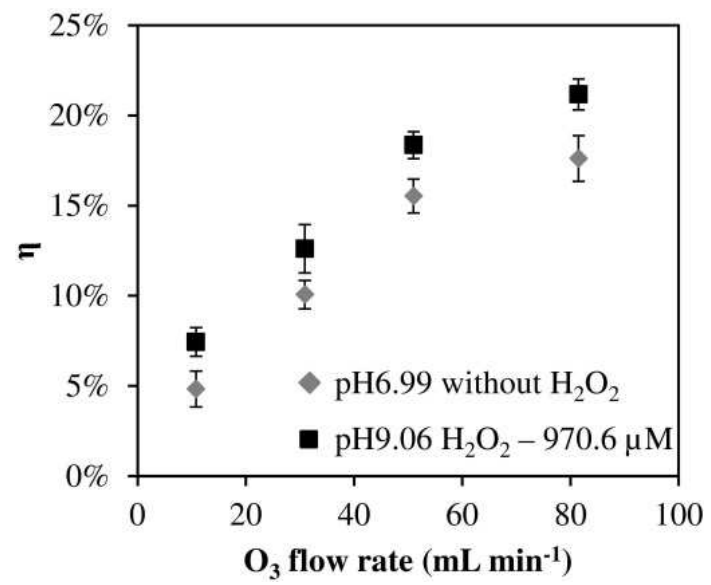

Figure 13 Removal efficiency of methanethiol in the packed-bed wet scrubber. Error bars represent the standard deviation from the replicates (Paper VI) 


\section{Conclusions}

The study from this PhD project is a step towards a better understanding of odour abatement by advanced oxidation processes; meanwhile, it is also a step towards the application of advanced oxidation processes in the livestock and industrial facilities. The presented results have confirmed the hypothesis that advanced oxidation processes have the potential of removing odorous compounds, but several challenges are also apparent. Based on the present PhD-thesis, the following can be concluded:

1) Photocatalytic monolith reactor is effective on removal of alcohol, carboxylic acids, methanethiol and dimethyl sulphide, and different initial concentrations and residence time $>0.1 \mathrm{~s}$ did not significantly affect the removal efficiency. However, removal of dimethyl disulphide was sensitive to the high air flow rate. Furthermore, UV intensity affected the photocatalysis reaction rate, especially to less reactive compounds (DMDS). However, only limited $\mathrm{H}_{2} \mathrm{~S}$ can be removed in the photocatalytic reactor in this study. Therefore, the application of the investigated technology is best suited for emissions that do not contain $\mathrm{H}_{2} \mathrm{~S}$.

2) Data obtained from PTR-MS can be used to determine the Langmuir-Hinshelwood parameters for highly volatile compounds with low adsorption and the uncertainties were $<20 \%$. It is the first time to provide the uncertainty of the Langmuir-Hinshelwood parameters based on the experimental data, and it is also demonstrated that the measurement by PTR-MS has relatively high precision and reproducibility.

3) By-products from photocatalytic reactor can be investigated by PTR-MS with complementation of GC/MS. PTR-MS can detect odorous compounds with high reactivity, such as MT, while GC/MS can detect more species unambiguously due to the chromatographic separation. Therefore, a number of byproducts are proposed in this study for the first time, such as methylthiomethanol, S-methyl thioformate for DMS, and dimethyl trisulphide and methyl(methylthio)methyl disulphide for DMDS. It should be aware that photocatalytic degradation of DMS did not change the environmental impact significantly compared to DMDS, due to the higher production of MT. In addition, formaldehyde was produced from photocatalytic oxidation of MT, DMS and DMDS.

4) A dissolved ozone sensor, based on a gas permeable polymer membrane, has been proved to be an accurate and time-resolved measurement on measuring low concentration of dissolved ozone.

5) The peroxone process $\left(\mathrm{O}_{3}+\mathrm{H}_{2} \mathrm{O}_{2}\right)$ is approved as a potential approach to purify the contaminated air in the bubble reactor. However, in the peroxone-based packed-bed wet scrubber, the removal of $\mathrm{H}_{2} \mathrm{~S}$ and DMS were mainly due to the direct reaction with $\mathrm{O}_{3}$, and $\mathrm{OH} \cdot$ radicals was only partially contributed ( $20 \%$ ). MT could not be effectively removed because of the slow reaction between MT and $\mathrm{O}_{3}$. Therefore, further research is necessary to increase the production of $\mathrm{OH}$. radicals in the packed-bed wet scrubber. 
In addition, the $\mathrm{O}_{3}$ emission at the outlet was relatively high and needs to be minimised in order for the process to be used in practise. 


\section{Further research perspectives}

The present $\mathrm{PhD}$-thesis has demonstrated the possibility to apply advanced oxidation processes on odour abatement, and PTR-MS is a promising method to monitor the reaction processes. However, there are still some challenges that have to be addressed. Further studies can develop the reactors with on-site test for both photocatalysis and peroxone process. Based on this $\mathrm{PhD}$-thesis, the following research perspectives can be identified:

1) A modification of $\mathrm{TiO}_{2}$ filter needs to be developed based on the honeycomb photocatalytic reactor in this study, so it can also effectively remove $\mathrm{H}_{2} \mathrm{~S}$.

2) Since the production of methanethiol (MT) and formaldehyde from photocatalytic oxidation were high, and both MT and formaldehyde is possible to react with $\mathrm{OH}$. radicals at high reaction rate, another $\mathrm{TiO}_{2}$ filters are necessary to install in the reactor in order to minimise the hazardous and odorous by-products.

3) A further step towards the application of advanced oxidation processes in the livestock and industrial facilities can be assessing the effect of photocatalytic reactor on purifying mixed odour gas stream,.

4) More researches are necessary to increase the production of $\mathrm{OH} \cdot$ radicals in the packed-bed wet scrubber, and to utilise $\mathrm{O}_{3}$ sufficiently. 


\section{References}

[1] R.W. Bottcher, An environmental nuisance: Odor concentrated and transported by dust, Chemical Senses, 26 (2001) 327-331.

[2] S. Nimmermark, Odour influence on well-being and health with specific focus on animal production emissions, Annals of Agricultural and Environmental Medicine, 11 (2004) 163-173.

[3] K. Radon, A. Schulze, V. Ehrenstein, R.T. van Strien, G. Praml, D. Nowak, Environmental exposure to confined animal feeding operations and respiratory health of neighboring residents, Epidemiology, 18 (2007) 300-308.

[4] M.J. Hansen, A.P.S. Adamsen, P. Pedersen, A. Feilberg, Prediction of Odor from Pig Production Based on Chemical Odorants, J. Environ. Qual., 41 (2012) 436-443.

[5] CEN. 2003. Air quality - determination of odour concentration by dynamic olfactometry. EN 13725. European Committee for Standardization, Brussels, Belgium.

[6] K.B. Andersen, M.J. Hansen, A. Feilberg, Minimisation of artefact formation of dimethyl disulphide during sampling and analysis of methanethiol in air using solid sorbent materials, Journal of Chromatography A, 1245 (2012) 24-31.

[7] M.J. Hansen, A.P.S. Adamsen, A. Feilberg, Recovery of Odorants from an Olfactometer Measured by Proton-Transfer-Reaction Mass Spectrometry, Sensors, 13 (2013) 7860-7871.

[8] F. Lestremau, V. Desauziers, J.C. Roux, J.L. Fanlo, Development of a quantification method for the analysis of malodorous sulphur compounds in gaseous industrial effluents by solid-phase microextraction and gas chromatography-pulsed flame photometric detection, Journal of Chromatography A, 999 (2003) 71-80.

[9] J. Larreta, A. Vallejo, U. Bilbao, A. Alonso, G. Arana, O. Zuloaga, Experimental design to optimise the analysis of organic volatile compounds in cow slurry by headspace solid-phase microextraction-gas chromatography-mass spectrometry, Journal of Chromatography A, 1136 (2006) 1-9.

[10] C. Cantau, S. Larribau, T. Pigot, M. Simon, M.T. Maurette, S. Lacombe, Oxidation of nauseous sulfur compounds by photocatalysis or photosensitization, Catalysis Today, 122 (2007) 27-38.

[11] K. Demeestere, J. Dewulf, B. De Witte, H. Van Langenhove, Titanium dioxide mediated heterogeneous photocatalytic degradation of gaseous dimethyl sulfide: Parameter study and reaction pathways, Applied Catalysis B-Environmental, 60 (2005) 93-106.

[12] H. Nishikawa, Y. Takahara, Adsorption and photocatalytic decomposition of odor compounds containing sulfur using $\mathrm{TiO}(2) / \mathrm{SiO}(2)$ bead, Journal of Molecular Catalysis a-Chemical, 172 (2001) 247-251.

[13] Z. Wang, J. Liu, Y. Dai, W. Dong, S. Zhang, J. Chen, Dimethyl Sulfide Photocatalytic Degradation in a Light-Emitting-Diode Continuous Reactor: Kinetic and Mechanistic Study, Industrial \& Engineering Chemistry Research, 50 (2011) 7977-7984.

[14] S. Trabue, K. Scoggin, F. Mitloehner, H. Li, R. Burns, H.W. Xin, Field sampling method for quantifying volatile sulfur compounds from animal feeding operations, Atmospheric Environment, 42 (2008) 3332-3341.

[15] J.A. Zahn, J.L. Hatfield, Y.S. Do, A.A. DiSpirito, D.A. Laird, R.L. Pfeiffer, Characterization of volatile organic emissions and wastes from a swine production facility, J. Environ. Qual., 26 (1997) 1687-1696.

[16] J.A. Koziel, J.P. Spinhirne, J.D. Lloyd, D.B. Parker, D.W. Wright, F.W. Kuhrt, Evaluation of sample recovery of malodorous livestock gases from air sampling bags, solid-phase microextraction fibers, Tenax TA sorbent tubes, and sampling canisters, Journal of the Air \& Waste Management Association, 55 (2005) 11471157.

[17] S.L. Trabue, J.C. Anhalt, J.A. Zahn, Bias of Tedlar bags in the measurement of agricultural odorants, J. Environ. Qual., 35 (2006) 1668-1677. 
[18] A.T. Nielsen, S. Jonsson, Trace determination of volatile sulfur compounds by solid-phase microextraction and GC-MS, Analyst, 127 (2002) 1045-1049.

[19] F. Lestremau, F.A.T. Andersson, V. Desauziers, Investigation of artefact formation during analysis of volatile sulphur compounds using solid phase microextraction (SPME), Chromatographia, 59 (2004) 607-613.

[20] F. Lestremau, F.A.T. Andersson, V. Desauziers, J.L. Fanlo, Evaluation of solid-phase microextraction for time-weighted average sampling of volatile sulfur compounds at ppb concentrations, Analytical Chemistry, 75 (2003) 2626-2632.

[21] J. de Gouw, C. Warneke, Measurements of volatile organic compounds in the earths atmosphere using proton-transfer-reaction mass spectrometry, Mass Spectrometry Reviews, 26 (2007) 223-257.

[22] A. Feilberg, A.P.S. Adamsen, S. Lindholst, M. Lyngbye, A. Schafer, Evaluation of Biological Air Filters for Livestock Ventilation Air by Membrane Inlet Mass Spectrometry, J. Environ. Qual., 39 (2010) 1085-1096.

[23] A. Feilberg, D.Z. Liu, A.P.S. Adamsen, M.J. Hansen, K.E.N. Jonassen, Odorant Emissions from Intensive Pig Production Measured by Online Proton-Transfer-Reaction Mass Spectrometry, Environmental Science \& Technology, 44 (2010) 5894-5900.

[24] S.S. Schiffman, J.L. Bennett, J.H. Raymer, Quantification of odors and odorants from swine operations in North Carolina, Agricultural and Forest Meteorology, 108 (2001) 213-240.

[25] S. Deshmukh, A. Jana, N. Bhattacharyya, R. Bandyopadhyay, R.A. Pandey, Quantitative determination of pulp and paper industry emissions and associated odor intensity in methyl mercaptan equivalent using electronic nose, Atmospheric Environment, 82 (2014) 401-409.

[26] J. Hoffmann, G. Gryglewicz, K. Hoffmann, S. Gryglewicz, W. Okereke, J. Skut, Emission of the odour substances from fertilizer industry, Polish Journal of Chemical Technology, 11 (2009) 12-15.

[27] R. Ranau, H. Steinhart, Identification and evaluation of volatile odor-active pollutants from different odor emission sources in the food industry, European Food Research and Technology, 220 (2005) 226-231.

[28] M. Skretowicz, I. Sowka, P. Sobczynski, U. Miller, Study on odour emission on industrial plants, Przemysl Chemiczny, 93 (2014) 1128-1131.

[29] D.B. Parker, Z.L. Perschbacher-Buser, N.A. Cole, J.A. Koziel, Recovery of Agricultural Odors and Odorous Compounds from Polyvinyl Fluoride Film Bags, Sensors (Basel, Switzerland), 10 (2010) 8536-8552.

[30] P.J. Hobbs, T.H. Misselbrook, M.S. Dhanoa, K.C. Persaud, Development of a relationship between olfactory response and major odorants from organic wastes, Journal of the Science of Food and Agriculture, 81 (2001) 188-193.

[31] L. Cai, J.A. Koziel, Y.-C. Lo, S.J. Hoff, Characterization of volatile organic compounds and odorants associated with swine barn particulate matter using solid-phase microextraction and gas chromatography-mass spectrometry-olfactometry, Journal of Chromatography A, 1102 (2006) 60-72.

[32] K.-H. Kim, E.-C. Jeon, Y.-J. Choi, Y.-S. Koo, The emission characteristics and the related malodor intensities of gaseous reduced sulfur compounds (RSC) in a large industrial complex, Atmospheric Environment, 40 (2006) 4478-4490.

[33] P.S. Coffey, M. Loppolo-Armanios, Identification of the odour and chemical composition of alumina refinery air emissions, Water Science and Technology, 50 (2004) 39-47.

[34] C. Easter, C. Quigley, P. Burrowes, J. Witherspoon, D. Apgar, Odor and air emissions control using biotechnology for both collection and wastewater treatment systems, Chem. Eng. J., 113 (2005) 93-104.

[35] S. Rappert, R. Muller, Odor compounds in waste gas emissions from agricultural operations and food industries, Waste Management, 25 (2005) 887-907.

[36] N.A. Zagustina, N.I. Krikunova, A.K. Kulikova, T.A. Misharina, M.E. Romanov, A.O. Ruzhitsky, M.B. Terenina, A.A. Veprizky, V.G. Zhukov, V.O. Popov, Composition of the air emission from a tobacco factory 
and development of the biocatalyst for odour control, Journal of Chemical Technology and Biotechnology, 85 (2010) 320-327.

[37] X. Li, T. Wang, C. Sattayatewa, D. Venkatesan, K.E. Noll, K.R. Pagilla, D.J. Moschandreas, Odor Emission Rate Estimation of Indoor Industrial Sources Using a Modified Inverse Modeling Method, Journal of the Air \& Waste Management Association, 61 (2011) 872-881.

[38] Y. Nagata, 2003, Measurement of odor threshold by triangle odor bag method.

[39] R.W. Melse, N.W.M. Ogink, Air scrubbing techniques for ammonia and odor reduction at livestock operations: Review of on-farm research in the Netherlands, Transactions of the Asae, 48 (2005) 2303-2313.

[40] H.J. Lin, X. Wu, C. Miller, J. Zhu, L.J. Hadlocon, R. Manuzon, L.Y. Zhao, Pilot-scale field study for ammonia removal from lagoon biogas using an acid wet scrubber, Journal of Environmental Science and Health Part B-Pesticides Food Contaminants and Agricultural Wastes, 49 (2014) 439-448.

[41] D. Panza, V. Belgiorno, Hydrogen sulphide removal from landfill gas, Process Safety and Environmental Protection, 88 (2010) 420-424.

[42] A. de Angelis, Natural gas removal of hydrogen sulphide and mercaptans, Applied Catalysis B: Environmental, 113-114 (2012) 37-42.

[43] K.-Y. Kim, H.-J. Ko, H.-T. Kim, Y.-S. Kim, Y.-M. Roh, C.-M. Lee, C.-N. Kim, Odor reduction rate in the confinement pig building by spraying various additives, Bioresource Technology, 99 (2008) 8464-8469.

[44] D.F. McCrory, P.J. Hobbs, Additives to reduce ammonia and odor emissions from livestock wastes: A review, J. Environ. Qual., 30 (2001) 345-355.

[45] A.C. Alvarado, B.Z. Predicala, D.A. Asis, Mixing nanoparticles with swine manure to reduce hydrogen sulfide and ammonia emissions, International Journal of Environmental Science and Technology, 12 (2015) 893904.

[46] E.R. Otto, M. Yokoyama, S. Hengemuehle, R.D. von Bermuth, T. van Kempen, N.L. Trottier, Ammonia, volatile fatty acids, phenolics, and odor offensiveness in manure from growing pigs fed diets reduced in protein concentration, J. Anim. Sci., 81 (2003) 1754-1763.

[47] E.T. Hayes, A.B.G. Leek, T.P. Curran, V.A. Dodd, O.T. Carton, V.E. Beattie, J.V. O'Doherty, The influence of diet crude protein level on odour and ammonia emissions from finishing pig houses, Bioresource Technology, 91 (2004) 309-315.

[48] E. Hartung, T. Jungbluth, W. Buscher, Reduction of ammonia and odor emissions from a piggery with biofilters, Transactions of the Asae, 44 (2001) 113-118.

[49] D. Liu, M.J. Hansen, L.B. Guldberg, A. Feilberg, Kinetic Evaluation of Removal of Odorous Contaminants in a Three-Stage Biological Air Filter, Environmental Science \& Technology, 46 (2012) 8261-8269.

[50] S. Kim, M.A. Deshusses, Understanding the limits of H2S degrading biotrickling filters using a differential biotrickling filter, Chem. Eng. J., 113 (2005) 119-126.

[51] W.H. Glaze, J.W. Kang, D.H. Chapin, THE CHEMISTRY OF WATER-TREATMENT PROCESSES INVOLVING OZONE, HYDROGEN-PEROXIDE AND ULTRAVIOLET-RADIATION, Ozone-Science \& Engineering, 9 (1987) 335-352.

[52] M. Antonopoulou, E. Evgenidou, D. Lambropoulou, I. Konstantinou, A review on advanced oxidation processes for the removal of taste and odor compounds from aqueous media, Water Research, 53 (2014) 215-234.

[53] M.S. Johnson, E.J.K. Nilsson, E.A. Svensson, S. Langer, Gas-Phase Advanced Oxidation for Effective, Efficient in Situ Control of Pollution, Environmental Science \& Technology, 48 (2014) 8768-8776.

[54] J.A. Manion, R.E. Huie, R.D. Levin, B.J.D. R., V.L. Orkin, W. Tsand, W.S. McGivern, J.W. Hudgens, V.D. Knyazev, D.B. Atkinson, E. Chai, A.M. Tereza, C.-Y. Lin, T.C. Allison, W.G. Mallard, F. Westley, J.T. Herron, R.F. Hampson, D.H. Frizzell, NIST Chemical Kinetics Database, NITS Standard Reference Database 17, 
Version 7.0 (Web Version), Release 1.6.8, Data version 2013.03, National Institute of Standards and Technology, Gaithersburg, Maryland, 20899-8320. Web address: http://kinetics.nist.gov/, (2013).

[55] D.R. Lide, CRC Handbook of Chemistry and Physics, 85th Edition, Taylor \& Francis, 2004.

[56] H. Kazuhito, I. Hiroshi, F. Akira, TiO 2 Photocatalysis: A Historical Overview and Future Prospects, Japanese Journal of Applied Physics, 44 (2005) 8269.

[57] W.H. Koppenol, J. Butler, Energetics of interconversion reactions of oxyradicals, Advances in Free Radical Biology \& Medicine, 1 (1985) 91-131.

[58] P. Polczynski, R. Jurczakowski, W. Grochala, Stabilization and strong oxidizing properties of Ag(ii) in a fluorine-free solvent, Chemical Communications, 49 (2013) 7480-7482.

[59] B. Hickel, K. Sehested, Reaction of hydroxyl radicals with ammonia in liquid water at elevated temperatures, International Journal of Radiation Applications and Instrumentation. Part C. Radiation Physics and Chemistry, 39 (1992) 355-357.

[60] M. Simić, P. Neta, E. Hayon, Pulse radiolytic investigation of aliphatic amines in aqueous solution, International Journal for Radiation Physics and Chemistry, 3 (1971) 309-320.

[61] B. Iddon, G.O. Phillips, K.E. Robbins, J.V. Davies, Radiation chemistry of aqueous solutions of indole and its derivatives, Journal of the Chemical Society B: Physical Organic, (1971) 1887-1892.

[62] W. Karmann, G. Meissner, A. Henglein, Pulsradiolyse des schwefel wasserstoffs in wassriger losung, Zeitschrift Fur Naturforschung Part B-Chemie Biochemie Biophysik Biologie Und Verwandten Gebiete, B 22 (1967) 273-282.

[63] W. Roebke, Schonesh.M, A. Henglein, Gamma-rasiolysis and pulse-radiolysis of carbon-disulfide aqueoussolution, Zeitschrift Fur Naturforschung Section B-a Journal of Chemical Sciences, B 28 (1973) 12-22.

[64] W. Karmann, A. Granzow, G. Meissner, A. Henglein, Die pulsradiolyse einfacher merkaptane in luft freier wässriger lösung, International Journal for Radiation Physics and Chemistry, 1 (1969) 395-405.

[65] M. Bonifacic, H. Mockel, D. Bahnemann, K.D. Asmus, Formation of positive ions and other primary species in the oxidation of sulphides by hydroxyl radicals, Journal of the Chemical Society, Perkin Transactions 2, (1975) 675-685.

[66] M. Bonifacic, K. Schaefer, H. Moeckel, K.D. Asmus, Primary steps in the reactions of organic disulfides with hydroxyl radicals in aqueous solution, The Journal of Physical Chemistry, 79 (1975) 1496-1502.

[67] M.N. Schuchmann, C. Vonsonntag, The rapid hydration of the acetyl radical - A pulse-radiolysis study of acetaldehyde in aqueous-solution, Journal of the American Chemical Society, 110 (1988) 5698-5701.

[68] N. Motohashi, Y. Saito, Competitive Measurement of Rate Constants for Hydroxyl Radical Reactions Using Radiolytic Hydroxylation of Benzoate, Chemical \& Pharmaceutical Bulletin, 41 (1993) 1842-1845.

[69] G.V. Buxton, C.L. Greenstock, W.P. Helman, A.B. Ross, Critical Review of rate constants for reactions of hydrated electrons, hydrogen atoms and hydroxyl radicals $(\cdot \mathrm{OH} / \cdot \mathrm{O}-$ in Aqueous Solution, Journal of Physical and Chemical Reference Data, 17 (1988) 513-886.

[70] J.K. Thomas, Rates of reaction of the hydroxyl radical, Transactions of the Faraday Society, 61 (1965) 702707.

[71] M.M. Fisher, W.H. Hamill, Electronic processes in pulse-irradiated aqueous and alcoholic systems, The Journal of Physical Chemistry, 77 (1973) 171-177.

[72] G. Scholes, R.L. Willson, [gamma]-Radiolysis of aqueous thymine solutions. Determination of relative reaction rates of OH radicals, Transactions of the Faraday Society, 63 (1967) 2983-2993.

[73] S.R. Logan, Redox reactions of organic radicals with ferrocene/ferricenium species in aqueous solution. Part 1. Radicals derived from carboxylic acids, Journal of the Chemical Society, Perkin Transactions 2, (1989) 751-754. 
[74] M. Anbar, D. Meyerstein, P. Neta, Reactivity of aliphatic compounds towards hydroxyl radicals, Journal of the Chemical Society B: Physical Organic, (1966) 742-747.

[75] R.J. Field, N.V. Raghavan, J.G. Brummer, A pulse radiolysis investigation of the reactions of bromine dioxide radical (BrO2.cntdot.) with hexacyanoferrate(II), manganese(II), phenoxide ion, and phenol, The Journal of Physical Chemistry, 86 (1982) 2443-2449.

[76] R.W. Matthews, D.F. Sangster, Measurement by Benzoate Radiolytic Decarboxylation of Relative Rate Constants for Hydroxyl Radical Reactions, The Journal of Physical Chemistry, 69 (1965) 1938-1946.

[77] J. Feitelson, E. Hayon, Electron ejection and electron capture by phenolic compounds, The Journal of Physical Chemistry, 77 (1973) 10-15.

[78] K. Clarke, R. Edge, V. Johnson, E.J. Land, S. Navaratnam, T.G. Truscott, Direct Observation of NH2• Reactions with Oxygen, Amino Acids, and Melanins, The Journal of Physical Chemistry A, 112 (2008) 12341237.

[79] R. Atkinson, R.A. Perry, J.N. Pitts, Rate constants for the reactions of the OH radical with (CH3)2NH, (CH3)3N, and $\mathrm{C} 2 \mathrm{H} 5 \mathrm{NH} 2$ over the temperature range $298-426^{\circ} \mathrm{K}$, The Journal of Chemical Physics, 68 (1978) 1850-1853.

[80] R. Atkinson, E.C. Tuazon, J. Arey, S.M. Aschmann, Atmospheric and indoor chemistry of gas-phase indole, quinoline, and isoquinoline, Atmospheric Environment, 29 (1995) 3423-3432.

[81] R. Atkinson, D.L. Baulch, R.A. Cox, J.N. Crowley, R.F. Hampson, R.G. Hynes, M.E. Jenkin, M.J. Rossi, J. Troe, Evaluated kinetic and photochemical data for atmospheric chemistry: Volume I - gas phase reactions of Ox, HOx, NOx and SOx species, Atmos. Chem. Phys., 4 (2004) 1461-1738.

[82] L. Masgrau, A. Gonzalez-Lafont, J.M. Lluch, Variational transition-state theory rate constant calculations of the $\mathrm{OH}+\mathrm{CH}(3)$ SHreaction and several isotopic variants, Journal of Physical Chemistry A, 107 (2003) 4490-4496.

[83] R. Atkinson, Kinetics and mechanisms of the gas-phase reactions of the hydroxyl radical with organic compounds under atmospheric conditions, Chemical Reviews, 86 (1986) 69-201.

[84] S.B. Barone, A.A. Turnipseed, A.R. Ravishankara, Role of adducts in the atmospheric oxidation of dimethyl sulfide, Faraday Discussions, 100 (1995) 39-54.

[85] N.I. Butkovskaya, D.W. Setser, Mechanism for the reaction of hydroxyl radicals with dimethyl disulfide, Chemical Physics Letters, 312 (1999) 37-44.

[86] C. Iuga, R. Esquivel Olea, A. Vivier-Bunge, Mechanism and Kinetics of the OH center dot Radical Reaction with Formaldehyde Bound to an $\mathrm{Si}(\mathrm{OH})(4)$ Monomer, Journal of the Mexican Chemical Society, 52 (2008) 36-46.

[87] L. Zhu, R.K. Talukdar, J.B. Burkholder, A.R. Ravishankara, Rate coefficients for the $\mathrm{OH}+$ acetaldehyde (CH3CHO) reaction between 204 and 373 K, International Journal of Chemical Kinetics, 40 (2008) 635-646.

[88] T.J. Dillon, D. Holscher, V. Sivakumaran, A. Horowitz, J.N. Crowley, Kinetics of the reactions of HO with methanol (210-351 K) and with ethanol (216-368 K), Physical Chemistry Chemical Physics, 7 (2005) 349-355.

[89] S.A. Cheema, K.A. Holbrook, G.A. Oldershaw, R.W. Walker, Kinetics and mechanism associated with the reactions of hydroxyl radicals and of chlorine atoms with 1-propanol under near-tropospheric conditions between 273 and 343 K, International Journal of Chemical Kinetics, 34 (2001) 110-121.

[90] C. Coeur-Tourneur, F. Henry, M.-A. Janquin, L. Brutier, Gas-phase reaction of hydroxyl radicals with m-, o-, and p-cresol, International Journal of Chemical Kinetics, 38 (2006) 553-562.

[91] R. Atkinson, D.L. Baulch, R.A. Cox, J.N. Crowley, R.F. Hampson, R.G. Hynes, M.E. Jenkin, M.J. Rossi, J. Troe, Evaluated kinetic and photochemical data for atmospheric chemistry: Volume II - gas phase reactions of organic species, Atmospheric Chemistry and Physics, 6 (2006) 3625-4055. 
[92] C. Zetzsch, F. Stuhl, Rate constants for reactions of $\mathrm{OH}$ with carbonic acids. Comm. Eur. Communities Rpt. 7624 (1982) 129.

[93] J.L. Acero, U. von Gunten, Influence of carbonate on the ozone/hydrogen peroxide based advanced oxidation process for drinking water treatment, Ozone-Science \& Engineering, 22 (2000) 305-328.

[94] A. Fujishima, X. Zhang, D.A. Tryk, Heterogeneous photocatalysis: From water photolysis to applications in environmental cleanup, International Journal of Hydrogen Energy, 32 (2007) 2664-2672.

[95] S. Sanches, M.T.B. Crespo, V.J. Pereira, Drinking water treatment of priority pesticides using low pressure UV photolysis and advanced oxidation processes, Water Research, 44 (2010) 1809-1818.

[96] B. Bianco, I. De Michelis, F. Veglio, Fenton treatment of complex industrial wastewater: Optimization of process conditions by surface response method, Journal of Hazardous Materials, 186 (2011) 1733-1738.

[97] D. Carini, U. von Gunten, I.J. Dunn, M. Morbidelli, Ozonation as pre-treatment step for the biological batch degradation of industrial wastewater containing 3-methyl-pyridine, Ozone-Science \& Engineering, 23 (2001) 189-198.

[98] Y. Lee, D. Gerrity, M. Lee, A.E. Bogeat, E. Salhi, S. Gamage, R.A. Trenholm, E.C. Wert, S.A. Snyder, U. von Gunten, Prediction of Micropollutant Elimination during Ozonation of Municipal Wastewater Effluents: Use of Kinetic and Water Specific Information, Environmental Science \& Technology, 47 (2013) 5872-5881.

[99] J.J. Macauley, Z. Qiang, C.D. Adams, R. Surampalli, M.R. Mormile, Disinfection of swine wastewater using chlorine, ultraviolet light and ozone, Water Research, 40 (2006) 2017-2026.

[100] P.F. Biard, A. Bouzaza, D. Wolbert, Photocatalytic degradation of two volatile fatty acids in an annular plug-flow reactor; Kinetic modeling and contribution of mass transfer rate, Environmental Science \& Technology, 41 (2007) 2908-2914.

[101] J. Lyu, L. Zhu, C. Burda, Considerations to improve adsorption and photocatalysis of low concentration air pollutants on TiO2, Catalysis Today, 225 (2014) 24-33.

[102] J.H. Mo, Y.P. Zhang, Q.J. Xu, J.J. Lamson, R.Y. Zhao, Photocatalytic purification of volatile organic compounds in indoor air: A literature review, Atmospheric Environment, 43 (2009) 2229-2246.

[103] M.R. Hoffmann, S.T. Martin, W. Choi, D.W. Bahnemann, Environmental Applications of Semiconductor Photocatalysis, Chemical Reviews, 95 (1995) 69-96.

[104] T. Daimon, Y. Nosaka, Formation and Behavior of Singlet Molecular Oxygen in TiO2 Photocatalysis Studied by Detection of Near-Infrared Phosphorescence, The Journal of Physical Chemistry C, 111 (2007) 44204424.

[105] X. Guo, Q. Li, M. Zhang, M. Long, L. Kong, Q. Zhou, H. Shao, W. Hu, T. Wei, Enhanced photocatalytic performance of $\mathrm{N}$-nitrosodimethylamine on $\mathrm{TiO} 2$ nanotube based on the role of singlet oxygen, Chemosphere, 120 (2015) 521-526.

[106] K. Chen, X. Huang, Y. Liu, M. Qi, Y. Hou, Y. Li, Y. Liang, X. Wang, W. Li, Q. Zhao, Photo-induced deposition of silver nanoparticles on periodically polarized lithium niobate, Chemical Physics Letters, 627 (2015) 82-86.

[107] J. Araña, J.M. Doña-Rodríguez, C.G.i. Cabo, O. González-Díaz, J.A. Herrera-Melián, J. Pérez-Peña, FTIR study of gas-phase alcohols photocatalytic degradation with $\mathrm{TiO} 2$ and $\mathrm{AC}-\mathrm{TiO} 2$, Applied Catalysis B: Environmental, 53 (2004) 221-232.

[108] J. Mo, Y. Zhang, Q. Xu, Y. Zhu, J.J. Lamson, R. Zhao, Determination and risk assessment of by-products resulting from photocatalytic oxidation of toluene, Applied Catalysis B: Environmental, 89 (2009) 570-576.

[109] D.F. Ollis, C.Y. Hsiao, L. Budiman, C.L. Lee, Heterogeneous photoassisted catalysis - conversions of perchloroethylene, dichloroethane, chloroacetic acid and chlorobenzenes, Journal of Catalysis, 88 (1984) 89-96. 
[110] M.L. Sauer, D.F. Ollis, Photocatalyzed oxidation of ethanol and acetaldehyde in humidified air, Journal of Catalysis, 158 (1996) 570-582.

[111] H. Yao, A. Feilberg, Characterisation of photocatalytic degradation of odorous compounds associated with livestock facilities by means of PTR-MS, Chem. Eng. J., 277 (2015) 341-351.

[112] R.M. Alberici, M.C. Canela, M.N. Eberlin, W.F. Jardim, Catalyst deactivation in the gas phase destruction of nitrogen-containing organic compounds using TiO2/UV-VIS, Applied Catalysis B: Environmental, 30 (2001) 389-397.

[113] N. González-García, J.A. Ayllón, X. Doménech, J. Peral, TiO2 deactivation during the gas-phase photocatalytic oxidation of dimethyl sulfide, Applied Catalysis B: Environmental, 52 (2004) 69-77.

[114] D.V. Kozlov, A.V. Vorontsov, P.G. Smirniotis, E.N. Savinov, Gas-phase photocatalytic oxidation of diethyl sulfide over TiO2: kinetic investigations and catalyst deactivation, Applied Catalysis B: Environmental, 42 (2003) 77-87.

[115] A. Alonso-Tellez, D. Robert, V. Keller, N. Keller, H2S photocatalytic oxidation over WO3/TiO2 Hombikat UV 100, Environmental Science and Pollution Research, 21 (2014) 3503-3514.

[116] R. Portela, M.C. Canela, B. Sánchez, F.C. Marques, A.M. Stumbo, R.F. Tessinari, J.M. Coronado, S. Suárez, H2S photodegradation by TiO2/M-MCM-41 $(\mathrm{M}=\mathrm{Cr}$ or $\mathrm{Ce})$ : Deactivation and by-product generation under UV-A and visible light, Applied Catalysis B: Environmental, 84 (2008) 643-650.

[117] R. Portela, B. Sanchez, J.M. Coronado, Photocatalytic oxidation of $\mathrm{H} 2 \mathrm{~S}$ on $\mathrm{TiO} 2$ and $\mathrm{TiO} 2-\mathrm{ZrO} 2$ thin films, Journal of Advanced Oxidation Technologies, 10 (2007) 375-380.

[118] Y. Lee, U. von Gunten, Oxidative transformation of micropollutants during municipal wastewater treatment: Comparison of kinetic aspects of selective (chlorine, chlorine dioxide, ferrate(VI), and ozone) and non-selective oxidants (hydroxyl radical), Water Research, 44 (2010) 555-566.

[119] J. Staehelin, J. Hoigne, Decomposition of ozone in water - Rate of initiation by hydroxide ions and hydrogen-peroxide, Environmental Science \& Technology, 16 (1982) 676-681.

[120] U. von Gunten, Ozonation of drinking water: Part I. Oxidation kinetics and product formation, Water Research, 37 (2003) 1443-1467.

[121] A. Fischbacher, J. von Sonntag, C. von Sonntag, T.C. Schmidt, The OH radical yield in the H2O 2 O3 (peroxone) reaction, Environmental Science \& Technology, 47 (2013) 9959-9964.

[122] J. Hoigne, H. Bader, Rate constants of reactions of ozone with organic and inorganic-compounds in water. 1. Non-dissociating organic-compounds, Water Research, 17 (1983) 173-183.

[123] J. Hoigne, H. Bader, Rate constants of reactions of ozone with organic and inorganic-compounds in water. 2. Dissociating organic-compounds, Water Research, 17 (1983) 185-194.

[124] J. Hoigne, H. Bader, W.R. Haag, J. Staehelin, Rate constants of reactions of ozone with organic and inorganic-compounds in water. 3. Inorganic compounds and radicals, Water Research, 19 (1985) 993-1004.

[125] C.C.D. Yao, W.R. Haag, Rate constants for direct reactions of ozone with severl drinking water contaminants, Water Research, 25 (1991) 761-773.

[126] Y.N. Lee, X.L. Zhou, Aqueous reaction-Kinetics of ozone and dimethyl sulfide and its atmospheric implications, Journal of Geophysical Research-Atmospheres, 99 (1994) 3597-3605.

[127] P. Neta, R.E. Huie, A.B. Ross, Rate constants for reactions of inorganic radicals in aqueous-solution, Journal of Physical and Chemical Reference Data, 17 (1988) 1027-1284.

[128] M.D. Gurol, S. Nekouinaini, Kinetic behavior of ozone in aqueous solutions of substituted phenols, Industrial \& Engineering Chemistry Fundamentals, 23 (1984) 54-60. 
[129] W.A. Pryor, D.H. Giamalva, D.F. Church, Kinetics of ozonation. 2. Amino acids and model compounds in water and comparisons to rates in nonpolar solvents, Journal of the American Chemical Society, 106 (1984) 7094-7100.

[130] R. Atkinson, S.M. Aschmann, D.R. Fitz, A.M. Winer, J.N. Pitts, Rate constants for the gas-phase reactions of O3 with selected organics at $296 \mathrm{~K}$, International Journal of Chemical Kinetics, 14 (1982) 13-18.

[131] S. Braslavsky, J. Heicklen, The gas-phase reaction of O3 with H2CO, International Journal of Chemical Kinetics, 8 (1976) 801-808.

[132] S. Glavas, S. Toby, Reaction between ozone and hydrogen sulfide, The Journal of Physical Chemistry, 79 (1975) 779-782.

[133] R.J. Glinski, D.A. Dixon, Chemiluminescent reactions of ozone with dimethyl sulfoxide and dimethyl disulfide. Formation of electronically excited sulfur dioxide, The Journal of Physical Chemistry, 89 (1985) 33-38.

[134] M.F.A. Hendrickx, C. Vinckier, 1,3-Cycloaddition of Ozone to Ethylene, Benzene, and Phenol: A Comparative ab Initio Study, The Journal of Physical Chemistry A, 107 (2003) 7574-7580.

[135] D.H. Stedman, H. Niki, Ozonolysis Rates of Some Atmospheric Gases, Environmental Letters, 4 (1973) 303-310.

[136] E.C. Tuazon, R. Atkinson, S.M. Aschmann, J. Arey, Kinetics and products of the gas-phase reactions of O3 with amines and related compounds, Res Chem Intermed, 20 (1994) 303-320.

[137] H.-t. Wang, Y.-j. Zhang, Y.-j. Mu, Temperature dependence of the absolute rate constant for the reaction of ozone with dimethyl sulfide, Journal of Environmental Sciences, 19 (2007) 641-643.

[138] A. Hansel, A. Jordan, C. Warneke, R. Holzinger, W. Lindinger, Improved detection limit of the protontransfer reaction mass spectrometer: On-line monitoring of volatile organic compounds at mixing ratios of a few PPTV, Rapid Communications in Mass Spectrometry, 12 (1998) 871-875.

[139] D. Papurello, L. Tognana, A. Lanzini, F. Smeacetto, M. Santarelli, I. Belcari, S. Silvestri, F. Biasioli, Proton transfer reaction mass spectrometry technique for the monitoring of volatile sulfur compounds in a fuel cell quality clean-up system, Fuel Processing Technology, 130 (2015) 136-146.

[140] K. Azrague, S.W. Osterhus, J.G. Biomorgi, Degradation of pCBA by catalytic ozonation in natural water, Water Science and Technology, 59 (2009) 1209-1217.

[141] H. Bader, V. Sturzenegger, J. Hoigné, Photometric method for the determination of low concentrations of hydrogen peroxide by the peroxidase catalyzed oxidation of N,N-diethyl-p-phenylenediamine (DPD), Water Research, 22 (1988) 1109-1115.

[142] L.S. Clesceri, A.D. Eaton, A.E. Greenberg, A.P.H. Association, A.W.W. Association, W.E. Federation, Standard Methods for the Examination of Water and Wastewater, American Public Health Association, 1998.

[143] M.C. Dodd, S. Zuleeg, U. Von Gunten, W. Pronk, Ozonation of Source-Separated Urine for Resource Recovery and Waste Minimization: Process Modeling, Reaction Chemistry, and Operational Considerations, Environmental Science \& Technology, 42 (2008) 9329-9337.

[144] T. Noethe, H. Fahlenkamp, C. von Sonntag, Ozonation of Wastewater: Rate of Ozone Consumption and Hydroxyl Radical Yield, Environmental Science \& Technology, 43 (2009) 5990-5995.

[145] A.T. Palin, Current DPD methods for residual halogen compounds and ozone in water, Journal American Water Works Association, 67 (1975) 32-33.

[146] H.S. Park, T.M. Hwang, J.W. Kang, H. Choi, H.J. Oh, Characterization of raw water for the ozone application measuring ozone consumption rate, Water Research, 35 (2001) 2607-2614.

[147] Y.Z. Pi, J. Schumacher, M. Jekel, The use of para-chlorobenzoic acid (pCBA) as an ozone/hydroxyl radical probe compound, Ozone-Science \& Engineering, 27 (2005) 431-436. 
[148] E. Rischbieter, H. Stein, A. Schumpe, Ozone solubilities in water and aqueous salt solutions, Journal of Chemical and Engineering Data, 45 (2000) 338-340.

[149] E.J. Rosenfeldt, K.G. Linden, S. Canonica, U. von Gunten, Comparison of the efficiency of center dot OH radical formation during ozonation and the advanced oxidation processes $\mathrm{O}-3 / \mathrm{H} 2 \mathrm{O} 2$ and $\mathrm{UV} / \mathrm{H} 2 \mathrm{O} 2$, Water Research, 40 (2006) 3695-3704.

[150] J. Staehelin, J. Hoigne, Decomposition of ozone in water in the presence of organic solutes acting as promoters and inhibitors of racidal chain reactions, Environmental Science \& Technology, 19 (1985) 1206-1213.

[151] M.S. Tango, G.A. Gagnon, Impact of ozonation on water quality in marine recirculation systems, Aquacultural Engineering, 29 (2003) 125-137.

[152] H. Bader, J. Hoigné, Determination of ozone in water by the indigo method, Water Research, 15 (1981) 449-456.

[153] M.S. Elovitz, U. von Gunten, Hydroxyl radical ozone ratios during ozonation processes. I-The R-ct concept, Ozone-Science \& Engineering, 21 (1999) 239-260.

[154] R.B. Lawson, C.D. Adams, Enhanced VOC absorption using the ozone/hydrogen peroxide advanced oxidation process, Journal of the Air \& Waste Management Association, 49 (1999) 1315-1323.

[155] J.L. Acero, U. Von Gunten, Characterization of oxidation processes: Ozonation and the AOP O3/H2O2, American Water Works Association Journal, 93 (2001) 90-100.

[156] P.-F. Biard, A. Couvert, C. Renner, J.-P. Levasseur, Assessment and optimisation of VOC mass transfer enhancement by advanced oxidation process in a compact wet scrubber, Chemosphere, 77 (2009) 182-187.

[157] J.-S. Park, H. Choi, J. Cho, Kinetic decomposition of ozone and para-chlorobenzoic acid (pCBA) during catalytic ozonation, Water Research, 38 (2004) 2285-2292.

[158] E.D. Boelter, G.L. Putnam, E.I. Lash, IODOMETRIC DETERMINATION OF OZONE OF HIGH CONCENTRATION, Analytical Chemistry, 22 (1950) 1533-1535.

[159] B.E. Saltzman, N. Gilbert, Iodometric microdetermination of organic oxidants and ozone - Resolution of mixtures by kinetic colorimetry, Analytical Chemistry, 31 (1959) 1914-1920.

[160] J. Mo, Y. Zhang, R. Yang, Novel insight into VOC removal performance of photocatalytic oxidation reactors, Indoor Air, 15 (2005) 291-300.

[161] S. Kato, Y. Hirano, M. Iwata, T. Sano, K. Takeuchi, S. Matsuzawa, Photocatalytic degradation of gaseous sulfur compounds by silver-deposited titanium dioxide, Applied Catalysis B: Environmental, 57 (2005) 109-115.

[162] J. Peral, D.F. Ollis, TiO2 photocatalyst deactivation by gas-phase oxidation of heteroatom organics, Journal of Molecular Catalysis A: Chemical, 115 (1997) 347-354.

[163] T. Tanizaki, Y. Murakami, Y. Hanada, S. Ishikawa, M. Suzuki, R. Shinohara, Titanium dioxide (TiO2)assisted photocatalytic degradation of volatile organic compounds at ppb level, Journal of Health Science, 53 (2007) 514-519.

[164] A.V. Vorontsov, E.V. Savinov, L. Davydov, P.G. Smirniotis, Photocatalytic destruction of gaseous diethyl sulfide over TiO(2), Applied Catalysis B-Environmental, 32 (2001) 11-24.

[165] J.T. Richardson, Y. Peng, D. Remue, Properties of ceramic foam catalyst supports: pressure drop, Applied Catalysis A: General, 204 (2000) 19-32.

[166] M.C. Canela, R.M. Alberici, R.C.R. Sofia, M.N. Eberlin, W.F. Jardim, Destruction of malodorous compounds using heterogeneous photocatalysis, Environmental Science \& Technology, 33 (1999) 2788-2792.

[167] X.Z. Li, M.F. Hou, F.B. Li, H. Chua, Photocatalytic oxidation of methyl mercaptan in foul gas for odor control, Industrial \& Engineering Chemistry Research, 45 (2006) 487-494. 
[168] W.K. Jo, M.H. Shin, Applicability of a continuous-flow system inner-coated with S-doped titania for the photocatalysis of dimethyl sulfide at low concentrations, Journal of Environmental Management, 91 (2010) 2059-2065.

[169] M. Tokumura, Y. Wada, Y. Usami, T. Yamaki, A. Mizukoshi, M. Noguchi, Y. Yanagisawa, Method of removal of volatile organic compounds by using wet scrubber coupled with photo-Fenton reaction - Preventing emission of by-products, Chemosphere, 89 (2012) 1238-1242.

[170] T.-x. Liu, X.-z. Li, F.-b. Li, Development of a Photocatalytic Wet Scrubbing Process for Gaseous Odor Treatment, Industrial \& Engineering Chemistry Research, 49 (2010) 3617-3622.

[171] N. Lu, H.T. Yu, Y. Su, Y. Wu, Water absorption and photocatalytic activity of TiO2 in a scrubber system for odor control at varying pH, Separation and Purification Technology, 90 (2012) 196-203.

[172] C. Sanchez, A. Couvert, A. Laplanche, C. Renner, Hydrodynamic and mass transfer in a new co-current two-phase flow gas-liquid contactor, Chem. Eng. J., 131 (2007) 49-58.

[173] S. Lacombe, H. Cardy, M. Simon, A. Khoukh, J.P. Soumillion, M. Ayadim, Oxidation of sulfides and disulfides under electron transfer or singlet oxygen photosensitization using soluble or grafted sensitizers, Photochemical \& Photobiological Sciences, 1 (2002) 347-354.

[174] V. Latour, T. Pigot, M. Simon, H. Cardy, S. Lacombe, Photo-oxidation of di-n-butylsulfide by various electron transfer sensitizers in oxygenated acetonitrile, Photochemical \& Photobiological Sciences, 4 (2005) 221-229.

[175] N. Lubna, G. Kamath, J.J. Potoff, N. Rai, J.I. Siepmann, Transferable potentials for phase equilibria. 8. United-atom description for thiols, sulfides, disulfides, and thiophene, Journal of Physical Chemistry B, 109 (2005) 24100-24107.

[176] M.C. Canela, R.M. Alberici, W.F. Jardim, Gas-phase destruction of H2S using TiO2/UV-VIS, Journal of Photochemistry and Photobiology A: Chemistry, 112 (1998) 73-80.

[177] S. Birk Rasmussen, R. Portela, S. Suarez, J. Manuel Coronado, M.-L. Rojas-Cervantes, P. Avila, B. Sanchez, Hybrid TiO2-SiMgOx Composite for Combined Chemisorption and Photocatalytic Elimination of Gaseous H2S, Industrial \& Engineering Chemistry Research, 49 (2010) 6685-6690.

[178] D. Liu, R.R. Andreasen, T.G. Poulsen, A. Feilberg, A comparative study of mass transfer coefficients of reduced volatile sulfur compounds for biotrickling filter packing materials, Chem. Eng. J., 260 (2015) 209-221. 